\title{
CAPITAL ACCOUNT LIBERALIZATION, INSTITUTIONS AND FINANCIAL DEVELOPMENT: CROSS COUNTRY EVIDENCE
}

\author{
Menzie D. Chinn \\ Hiro Ito \\ Working Paper 8967 \\ http://www.nber.org/papers/w8967 \\ NATIONAL BUREAU OF ECONOMIC RESEARCH \\ 1050 Massachusetts Avenue \\ Cambridge, MA 02138 \\ June 2002
}

Helpful comments were received from Joshua Aizenman, Michael Hutchison, Carl Walsh, Frank Warnock, participants at the UCSC brown bag, the USC development seminar and, on an earlier version of the paper, the ANU-IMF East Asia Office conference on "Regional Financial Markets" (Sydney, November 2001). We also thank Ashok Mody and Dennis Quinn for providing data. Financial support of faculty research funds of UC Santa Cruz are gratefully acknowledged. The views expressed herein are those of the authors and not necessarily those of the National Bureau of Economic Research.

(C) 2002 by Menzie D. Chinn and Hiro Ito. All rights reserved. Short sections of text, not to exceed two paragraphs, may be quoted without explicit permission provided that full credit, including $($ C notice, is given to the source. 
Capital Account Liberalization, Institutions and Financial Development:

Cross Country Evidence

Menzie D. Chinn and Hiro Ito

NBER Working Paper No. 8967

June 2002

JEL No. F36, F43, G28

\begin{abstract}
The empirical relationship between capital controls and the financial development of credit and equity markets is examined. We extend the literature on this subject along a number of dimensions. Specifically, we (1) investigate a substantially broader set of proxy measures of financial development; (2) create and utilize a new index based on the IMF measures of exchange restrictions that incorporates a measure of the intensity of capital controls; and (3) extend the previous literature by systematically examining the implications of institutional (legal) factors. The results suggest that the rate of financial development, as measured by private credit creation and stock market activity, is linked to the existence of capital controls. However, the strength of this relationship varies with the empirical measure used, and the level of development. These results also suggest that only in an environment characterized by a combination of a higher level of legal and institutional development will the link between financial openness and financial development be readily detectable. A disaggregated analysis indicates that in emerging markets the most important components of these legal factors are the levels of shareholder protection and of accounting standards.
\end{abstract}

Menzie D. Chinn

Department of Economics

Social Sciences I

University of California

Santa Cruz, CA 95064

and NBER

Tel: (831) 459-2079

Fax: (831) 459-5900

Email: chinn@cats.ucsc.edu
Hiro Ito

Department of Economics

Social Sciences I

University of California

Santa Cruz, CA 95064

Email: hiroito@cats.ucsc.edu 


\section{Introduction}

Recent years have witnessed a resurgence of interest in financial development as a key driver of economic growth. ${ }^{1}$ At the same time, the effects of capital controls have taken center stage in a number of policy debates, especially in the wake of the East Asian currency crises. ${ }^{2}$ Hence, it appears appropriate to now direct analytical attention to the question of whether capital controls are compatible with financial development. The centerpiece of our discussion will be an econometric analysis, using aggregate data on a large sample of countries over the 1977-1997 period.

The analysis in this paper departs from that found in much of the extant literature. First, the analysis skirts the financial development-growth versus capital liberalization-growth debate, and restricts its attention to the linkage between capital liberalization and financial development. Second, a larger set of financial development measures is used, including those pertaining to equity markets. Third, a larger set of measures on restrictions on international financial transactions is used. That translates into use of all the IMF's indicators of exchange restrictions with the incorporation of their intensity. Fourth, cross-country differences in the legal and institutional environment for financial transactions are also incorporated in our analysis, which will allow us to investigate their impact on the effectiveness of capital liberalization on financial development.

Section 2 is reviews the relevant literature, while Section 3 presents the model specification, data description, and empirical results. In Section 4 the focus is expanded to include the influence of legal and institutional foundations on financial development. Concluding remarks are in Section 5.

\section{A Selective Review of the Literature}

In contrast to the large body of cross-country work investigating the link between finance and growth, literature examining the link between capital controls and/or financial openness and financial development is fairly small. One paper of interest is by De Gregorio (1998). He examines the related

\footnotetext{
${ }^{1}$ See for instance Leahy, et al. (2001) for OECD-specific results. Klein and Olivei (2001) document the linkage for developed countries, and its absence for less developed countries. Spiegel (2001) examines an APEC sample, while Arteta, Eichengreen and Wyplosz (2001) document the fragility of many of these group-specific results. IMF (2001, Chapter 4) surveys both the growth and finance, and finance and liberalization literature. For the most recent review on finance and growth, refer to Quinn, et al. (2002)

${ }^{2}$ In this study we do not discuss the merits of capital controls in the context of financial crises. For a review, see Aizenman (2002). Kletzer and Mody (2000) survey the debate in the context of "self-protection policies" for emerging markets.
} 
question of whether economies exhibiting greater financial integration experience greater financial development. Instead of relying upon financial restrictions of a regulatory nature, he investigates the effect of lack of financial integration characterized by deviations from two no arbitrage profits conditions, the international arbitrage pricing model (IAPM) of Levine and Zervos (1995) and the international capital asset pricing model (ICAPM) of Levine and Zervos (1998).

After controlling for inflation rates and trade openness, De Gregorio finds that in a cross-section of developing and industrialized countries, the no-arbitrage profits conditions have a positive and statistically significant effect upon the lending, stock market capitalization and volatility measures of financial deepening. The total value of shares traded per year measure only appears to depend upon the ICAPM measure.

In these analyses, one important distinction is that between behavior in developed and developing countries. In the sample for which De Gregorio has data on the gross capital flows and composite measures, the observations are restricted to developing countries. In these samples, he finds only mixed evidence for any of these two measures having an effect. Gross capital flows do appear to be correlated with the lending measure of financial deepening, an intuitive finding; at the same time, this is the least convincing measure of the variable of interest. ${ }^{3}$

More recently, Klein and Olivei (2001) examine a cross-section of 87 industrialized and less developed countries over the 1976-1995 period. Their agenda actually includes both the link between financial development and economic growth, as well as the nexus of liberalization and finance we are interested. Here, we merely recount the results pertinent to the question at hand. Their regressions take the form of:

(1) $\quad F D_{t}^{i}-F D_{t-k}^{i}=\beta_{0}+\beta_{1} F D_{t-k}^{i}+\beta_{2} K A L I B_{t-k, t}^{i}+\beta_{3} X^{i}+\varepsilon_{t}^{i}$

where $F D$ is the financial development variable, $K A L I B$ is the capital account liberalization variable, and $\boldsymbol{X}$ is a set of control variables, including regional and time dummies.

Their measures of financial development include the ratio of liquid liabilities to GDP, the proportion of financial intermediates' claims on the private sector to GDP, and the ratio of private bank to private plus central bank assets. Each of these measures has strengths and weaknesses. The

\footnotetext{
${ }^{3}$ Unfortunately, De Gregorio (1998) does not report results for the no-arbitrage profits measures broken down by developing and developed countries. This is probably due to the small number of observations (there are about 24
} 
liquid liabilities measure is the most common measure of financial development; it consists of the sum of currency outside the banking system, plus demand and interest bearing liabilities of the banking system. This measure, however, does not distinguish between allocation to private and public sector entities, and hence could misleadingly indicate that a country with directed lending to state owned enterprises actually had a advanced financial system, when in fact the banking system was failing in its role as project monitor. The private claims measure addresses this deficiency, and is similar to the series used by De Gregorio. Both of these data series are readily available. Finally, the commercial bank assets ratio is meant to focus on the development of those services that are most related to financial management.

For $K A L I B$, Klein and Olivei use the most common measure of capital account liberalization - the IMF's indicator variable on capital account restrictions from the Annual Report on Exchange Arrangements and Exchange Restrictions (AREAER) - or for a subset of industrialized countries, the OECD measure of capital account liberalization.

Comfortingly, Klein and Olivei find a relationship between capital account liberalization and financial development. However, one marked and notable aspect of their results is that the identified correlation is driven entirely by the developed countries in their sample. In other words, there is no detectable relationship between liberalization and development for the less developed countries. Klein and Olivei conjecture that this result obtains because the less developed countries were latecomers to the liberalization game; hence it may merely be the case that the effects of liberalization have not yet been felt, and that time will tell.

To our knowledge, analyses with a similar cross-country breadth to the Klein and Olivei study have not been performed for stock or bond market measures, although there have a number of papers focusing on growth effects of liberalizing access to equity markets. ${ }^{4}$ Consequently, it appears useful to re-examine the issues raised by the previous studies systematically.

\section{An Econometric Analysis of Financial Openness and Development}

The analysis that we conduct takes a broad view of financial development - that is it includes the lending measures typically used, but also incorporates various measures of the equity markets. In

\footnotetext{
observations per integration measure).

${ }^{4}$ See Bekaert et al. (2000) for growth, and Chari and Henry (2002) for investment, for instance. Henry (2000) evaluates the liberalization effects on abnormal returns in a short window, which is tangentially related to some of our measures of equity market development.
} 
some respects, the development of equity markets may be a better measure of the ability of an economy to mobilize capital in an efficient manner; conventional measures of lending activity are susceptible to mis-characterizing government directed lending as market driven lending. Hence, a variety of financial deepening measures are used, although results from only a subset of the measures analyzed will be reported.

\subsection{The Empirical Specification}

In principle, one would like to estimate the long run equilibrium relationship in:

$$
F D_{t}^{i}=\gamma_{0}+\gamma_{1} K A O P E N_{t}^{i}+X_{t}^{i} \Gamma+u_{t}^{i}
$$

where KAOPEN is a measure of capital openness (or an inverse of a measure of capital controls), and $X$ is a vector of economic control variables. The capital control variables are described in greater detail in the data section. Here we focus on the economic rationale underpinning the other right hand side variables, in the $\boldsymbol{X}$ vector, which could in principle include a very large number of variables. In this analysis, the set is kept fairly small, so as to retain some interpretability of the correlations. The economic variables include log per capita income in PPP terms, the inflation rate, and trade openness, measured as the ratio of the sum of exports and imports to GDP.

Log per capita income is included as there is a long literature ascribing financial deepening, aside from the role of regulation, to the increasing complexity of economic structures associated with rising income. The inflation rate is included because it (or the volatility in the inflation rate) ) $^{5}$ ay cause distortions in decision-making regarding nominal magnitudes. In particular, moderate to high inflation may discourage financial intermediation, and encourage saving in real assets. Finally, trade openness is included as an ad hoc control; many empirical studies find a correlation of trade openness with any number of economic variables.

It turns out that it is difficult to control for secular trends in financial deepening in the context of the panel regression in levels, as in equation $2 .{ }^{6}$ This is most likely due to the large cyclical

\footnotetext{
${ }^{5}$ Since in most cases, the volatility of inflation rises with the inflation rate, the inflation rate could be proxying for either or both of these effects.

${ }^{6}$ See Chinn (2001) for some representative regression results using individual measures of controls from the IMF.
} 
variations in the financial deepening variables, along with trending behavior of the variables of interest. Hence, an alternative specification, akin to a panel error-correction model, is estimated:

$$
F D_{t}^{i}-F D_{t-5}^{i}=\gamma_{0}+\rho F D_{t-5}^{i}+\gamma_{1} K A O P E N_{t-5}^{i}+X_{t-5}^{i} \Gamma+u_{t}^{i}
$$

This regression carries with it the following interpretation: The rate of financial development depends inversely upon the level of financial development, negatively upon the extent of capital controls (or positively upon the degree of financial openness), and upon a series of economic control variables. ${ }^{7}$

The use of the long horizon of five years (the average annual growth rate over a five year period) has two advantages. First, it serves to minimize the effect of correlations due to business cycle fluctuations. Second, relating the growth rate between period $t-5$ and period $t$ to the level of variables dated at time $t-5$ serves to mitigate endogeneity problems. Specifically, in regressions of either the level or the growth rate of financial development on variables such as per capita income or more importantly capital controls, one could easily imagine two way causality at the annual frequency. For instance, increases in the ratio of private credit to GDP might cause more rapid GDP growth. Or increasing stock market capitalization might induce policymakers to have a less sanguine view of the effects of capital controls. Analyzing the data at five year horizons mitigates (but does not completely solve) this problem.

The drawback, of course, is that one is throwing away some data by using average growth rates (non-overlapping panel analysis), and sampling the "initial conditions" at every five years. The ideal solution would be to purge the data of cyclical fluctuations and instrument the right hand side variables; in a large panel study of this nature, it is difficult to implement such econometric techniques in a manner that is appropriate, so we resort to simpler and more readily interpretable methods. In any event, this approach is common to the literature (and in our opinion is preferred to pure cross section regressions that examine growth over a very long horizon such as 20 years).

\subsection{Data}

The data are drawn from a number of sources, primarily the World Bank's World Development Indicators, the IMF's International Financial Statistics, and the databases associated 
with Beck, Kunt, and Levine (2000). The analysis is based upon data originally recorded at an annual frequency, over the 1970-1997 period, covering 105 countries. Details are reported in Appendix 1.

\subsubsection{Financial Development Indicators.}

A large number of indicators were examined; only a subset actually used in the analysis, or discussed in the text, are described below (the remaining are described in Appendix 1). The first set is the most familiar: $L L Y$ is liquid liabilities to GDP ratio, while $P C G D P$ is the ratio of private credit from deposit money banks to the private sector. ${ }^{8}$ The second set is slightly less familiar, and applies to the equity markets. $S M K C$ is the ratio of the stock market capitalization to GDP, SMTV is the ratio of total value of stocks traded to GDP, and SMTO is the stock market turn over ratio. EQTY is the equity issues to GDP ratio.

Finally, there are a series of measures that pertain to the bond markets. Unfortunately, the number of observations is quite small, and the cross-country coverage quite narrow. ${ }^{9}$ For instance, there are only about 140 annual observations on long-term private debt issues, while there are over 1900 on the liquid liabilities measures. When the specification involves five year growth rates, the number of observations is so small that we are unable to obtain any interesting results for this particular aspect of financial development, even though long term financing through bonds is likely to be an important factor in economic development (See for example Herring and Chatusripitak (2000)).

Figure 1 shows annual observations on three key measures of financial deepening (liquid liabilities, private credit, and stock market capitalization). There is a clear correlation between the two banking sector related measures, while the relationship with capitalization is less obvious. The top seven rows of Table 1 report summary statistics for financial development indicators including these variables, while Table 2 reports the correlation coefficients.

\footnotetext{
${ }^{7}$ We also included time fixed effects to capture possible time-specific exogenous shocks.

${ }^{8}$ Many researchers use the ratio of M2 (the sum of M1 and quasi money) to GDP (M2Y in our data set). However, since the correlation between liquid liabilities $(L L Y)$ and $\mathrm{M} 2$ ratios is quite high (see Table 1 for summary statistics and Table 2 for the correlation coefficients), and the results do not differ substantially when using one or the other variable, M2 will not be discussed in this paper.

${ }^{9}$ Data are available for the following series: $P V B M$, the private bond market capitalization to GDP ratio; $P B B M$, the public bond market capitalization to GDP ratio; and $L T P D$ is the long term private debt issues to GDP ratio.
} 


\subsubsection{Quantifying Capital Controls}

There is no question that it is extremely difficult to measure the extent of capital account controls. Many measures have been created to describe the extent and intensity of capital account controls. However, there is a general impression that most extant measures fail to capture the complexity of real-world capital controls. ${ }^{10}$ This view prevails because regulatory limitations on capital flows have a multidimensional character, allowing policy makers many options. Since different restrictions can have different implications for economic performance, capital restrictions can differ depending upon the intension of policy makers and the economic state where they are in. Moreover, it is almost impossible to distinguish between de jure and de facto controls on capital transactions as seen in the case of multiple exchange rates systems in many developing countries and the mandatory reserve requirement in Chile in the 1990's. ${ }^{11}$

Most of analyses of either effects of capital controls, or their determinants, rely upon the IMF's categorical enumeration, reported in Annual Report on Exchange Arrangements and Exchange Restrictions (hereafter AREAER). AREAER provides information on the extent and nature of the restrictions on external accounts for a wide cross-section of countries. In this set of "on-off" clarification, $k_{l}$ is an indicator variable for the existence of multiple exchange rates, while $k_{4}$ is a variable indicating the requirement of the surrender of export proceeds. The most relevant capital controls are $k_{2}$ and $k_{3}$. They indicate restrictions on current account and capital account transactions, respectively.

The eighth through eleventh rows of Table 1 report summary statistics for these capital control measures. ${ }^{12}$ Restrictions on the capital account and the surrender of export proceeds appear to be the most pervasive. However, all of these capital controls appear to be decreasing in their use (although one cannot conclude that they are decreasing in terms of how tightly they bind).

The deficiencies of these dichotomous measures of capital controls are well known. The most obvious is that they do not measure the intensity of the controls, nor do they speak to their efficacy (in

\footnotetext{
${ }^{10}$ See Edison and Warnock (2001), Edwards (2001), and Edison et al. (2002) for discussions and comparisons of various measures on capital restrictions.

${ }^{11}$ Dooley (1996) provides an extensive literature review and Neely (1999) presents a descriptive overview on capital controls

${ }_{12}$ As we will explain later, we reversed binary variables of the AREAER series in order to focus on the effect of financial openness, not controls. Therefore, the more pervasive capital controls are, the $k_{i}$ variables tend to be closer to zero. Also, a positive average growth rate means that capital controls are less and less in use.
} 
this regard, one might prefer the outcome-based measures De Gregorio uses). ${ }^{13}$ To illustrate this assertion, note that for instance, capital controls might be as stringent and command-and-control oriented as those imposed by the Latin American governments in the wake of the 1980's debt crises, or of a less dirigiste form such as the Chilean controls. ${ }^{14}$

A common method used to overcome the deficiencies of the dichotomous measures of capital controls entails the construction of variables that depend on the proportion of years in the examined window for which countries had liberalized capital accounts using the AREAER variables (See Edwards (2001) and Klein and Olivei (2001) ${ }^{15}$ ). However, as Edison et al. (2002) admit, a drawback of this method is that such indicators do not convey any information about whether the country is on its way to liberalizing or restricting its capital accounts. In concrete terms, a value of 0.5 can indicate that the capital account was closed the first half of the period, and open the second, or vice versa. Quinn (1997) has recently compiled a composite measure of financial regulation that ranges from 0 to 14 , with 14 representing the least regulated and most open regime. The bulk of the index is based upon Quinn's coding of the qualitative information contained in the various issues of $A R E A E R$ pertaining to $k_{2}$ and $k_{3}$, augmented by information regarding whether the country in question has entered into international agreements with international organizations such as the OECD and European Union.

Considering the deficiencies of the AREAER variables, it might be preferable to implement the empirical analysis using this set of Quinn variables. However, while a complete tabulation for the OECD members exists, the coverage for the less developed countries is much less extensive; values are reported only for certain years $(1958,1973,1982$, and 1988).

Hence, an index based on the $A R E A E R$ binary series is constructed with the goal of incorporating the intensity of capital controls. Our index on capital controls is the first standardized principal component of the aforementioned $k_{l}$ through $k_{4}$ binary variables. Also, in order to focus on the effect of financial openness - rather than controls - we reverse the values of the binary variables

\footnotetext{
13 There had also been criticism that the dichotomous measures based on the AREAER fail to distinguish between the types of flow that are being restricted. In 1997, AREAER started publishing the data on disaggregated components of capital controls, with the specification of thirteen categories including, for the first time, a distinction between restrictions on inflows and outflows as well as between different types of capital transactions. See Johnston and Tamirisa (1998) for a descriptive overview and statistical analysis on the disaggregated data of AREAER.

14 Specifically the unrenumerated reserve requirements (URR), that sought to discourage short term capital inflows and hence outflows. See Edwards (1998, 1999)

15 Edison et al. (2002) articulately reviews and compares different methods of quantifying capital controls.
} 
of the AREAER series, such that the variable takes a value of unity when the restrictions are non-existent. Moreover, for controls on capital transactions $\left(k_{3}\right)$, we use the share of a five year window that controls were not in effect (SHAREk $k_{3}$ ). Specifically, the financial openness variable for year $t$ is proportion of five years encompassing year $t$ and the preceding four years that the capital account was open:

$\operatorname{SHAREk}_{3, t}=\left(\frac{k_{3, t}+k_{3, t-1}+k_{3, t-2}+k_{3, t-3}+k_{3, t-4}}{5}\right)$

Hence, our index for capital "openness" is,

$K A O P E N_{t}=$ the first standardized principal component of $k_{1, t}, k_{2, t}, S H A R E k_{3, t}$, and $k_{4, t}$,

which takes on higher values the more open the country is to cross-border capital transactions.

The thirteenth row of Table 1 reports the summary statistics of KAOPEN. By construction, the KAOPEN series are mean of zero. The table shows that the average of KAOPEN among the countries is growing at $3.8 \%$ annually. The first eigenvector for $K A O P E N$ was found to be $\left(S_{H A R E k}, k_{1}, k_{2}, k_{4}\right)^{\prime}=(0.563,0.280,0.516,0.582)^{\prime}$, indicating that the variability of KAOPEN is not merely driven by the SHAREk $k_{3}$ series.

The incorporation of the $k_{l, t}, k_{2, t}$, and $k_{4, t}$ variables merits some discussion. We interpret these variables as indicators of the intensity of the capital controls. This point can be made more concrete by considering a country with an open capital account. It may still restrict the flow of capital by limiting transactions on the current account restrictions or other systems such as multiple exchange rates and requirements to surrender export proceeds. Alternatively, countries that already have closed capital accounts might try to increase the stringency of those controls by imposing $k_{l}, k_{2}$, and $k_{4}$ types of restrictions so that the private sector cannot circumvent the capital account restrictions. ${ }^{16}$ Since our indicator incorporates these other controls, one could interpret our measure as a variant of the ones used by Edwards (2001) and Klein and Olivei (2001).

${ }^{16}$ Grilli and Milesi-Ferretti also tried to overcome the issue of intensity of the AREAER variables by employing the binary variables for current account restrictions and multiple exchange rate practices, but not the one for export proceeds surrender), though they used these variables individually in their regression models. 
An alternative principal components-based measure, incorporating black market foreign exchange premia, was also considered. However, the empirical results obtained using this alternative measure were very similar to those obtained using our basic index. Consequently, we opted to report results using only the first principal component of $S H A R E k_{3}, k_{1}, k_{2}$, and $k_{4}$ alone.

To check the robustness of our analysis based on the KAOPEN index, we also use a Quinn measure of financial regulation. However, since the measure is not complete for the developing countries, a linear imputation method is employed to fill the missing variables of those countries based on the regression of the actual Quinn series on the AREAER $k_{i}$ variables. For more detailed explanations on this imputation method, refer to Appendix 2.

\subsection{Results}

Figure 2 illustrates the correlation between private credit (PCGDP) and stock market capitalization $(S M K C)$ on one hand, and the first principal component of financial openness (KAOPEN). The PCGDP series appears to vary in the expected manner with the capital openness proxy (positively), while the association between $S M K C$ and the capital openness variable is indecisive. However, one has to recall that financial development and the absence of capital controls can be both positively correlated with other economic variables such as per capita income. Hence, the positive association visible in Figure 3, even if it exists, may not survive regression analysis.

Table 3 reports the results estimating equation (3) over the entire sample. Columns 1 and 2 show the regression results on the relationship between financial openness and the development of bank credit markets, whereas Columns 3 through 6 on the relationship between financial openness and equity market development. The change in private credit (column 2) appears to be closely linked to financial openness, and that in liquid liabilities (column 1) appears to be weakly linked. Per capita income and trade openness enter in with the expected positive sign in almost all cases, as does inflation with the negative sign. In the results using the equity market measures, only the growth rate of stock market value traded - a more representative indicator of equity market activity than stock market capitalization - is significantly affected by financial openness (column 4). In general, however, the proportion of variation explained in the equity market development indicators is higher than in the cases using the bank credit measures.

It is possible that these observed patterns are being driven by the decision to pool both industrialized and less developed economies into one sample. This applies to both the apparent 
sensitivity of equity market indicators to financial openness, and the absence of any relationship of bank credit measures to financial openness. Hence, Table 4 presents the results for two different developing country samples.

The first six columns of Table 4 show the results for a subsample of less developed countries (under the LDC heading). Unlike the full sample case, bank credit indicators (columns 1 and 2) do not appear to be affected by financial openness. Among the equity market indicators, again, the measure of equity market activity (value traded, column 4) appears to be significantly influenced by financial openness (with the $p$-value of 9\%). This result illustrates that in the less developed countries one unit of increase in financial openness can lead to a $0.5 \%$ acceleration in the growth rate of the stock market value traded ratio.

Another subset of countries yields more interesting results. The last six columns of Table 4 display the results of the same study conducted on the emerging market countries (EMG). ${ }^{17}$ While financial openness previously did not appear to significantly affect bank credit creation in the LDC subsample, it does appear to have a significant impact among the EMG countries on bank credit development in terms of private credit creation (column 8). Interestingly, the measures of equity market development (columns 10 through 12) except for stock market capitalization appear to be statistically significant upon financial openness (the $p$-value for the equity issued variable is 16\%), out of which only the measure of stock market value traded was significantly linked to financial openness in the full sample and developing countries subsample cases.

The magnitude of the effect of financial openness is quite different between the LDC and EMG subsamples. For example, between 1992 and 1997, Argentina, an EMG country, increased its openness in terms of KAOPEN from -1.09 to 2.09. The results shown in Column 10 of Table 4 show that this 3.18 unit increase in $K A O P E N$, other things being equal, implies an acceleration of the annual growth rate of Argentina's stock market value traded by $2.1 \%$, whereas the same amount of increase in financial openness implies only a $1.6 \%$ annual growth for a typical non-emerging market LDC. ${ }^{18}$ Moreover, while financial openness has a nil effect on stock market turnover among LDCs, the magnitude of its effect is significantly high among the EMG countries (for Argentina, the same

\footnotetext{
${ }^{17}$ See the Country List for a full list of the emerging market countries. The definition of the emerging market countries is based on Bekaert, Harvey, and Lundblad (2000) where they define as emerging market countries the thirty countries which are classified by the IFC (World Bank) as either emerging or frontier during the period of 1980-1997.

${ }^{18}$ In fact, KAOPEN for Uruguay, categorized as an LDC, increased by 0.46 between 1992 and 1997, implying an acceleration of merely $0.2 \%$.
} 
change in $K A O P E N$ as in the previous case could have led to an annual growth of $4.3 \%$ ). A one unit increase in financial openness can raise private credit growth in the EMG by $0.5 \%$, an effect that is not only higher than that exhibited in the LDC sample, but also in the full sample. Clearly, there is a sharp difference in the effect of financial openness on financial development, in terms of both bank credit creation and equity market development, between the LDC and EMG categories, with the latter group of countries possibly reaping more from financial openness.

The econometric analysis thus confirms what other studies have found - namely that the relationship between the removal of capital controls and bank credit measures of financial development does not hold for developing countries. On the other hand, among the emerging market countries, both bank credit and equity market development do appear to be linked to financial openness in a significant manner, thus yielding a perspective on the relationship between capital controls and financial development that is more nuanced than that in the extant literature.

\subsection{Robustness Checks ${ }^{19}$}

\subsubsection{Analysis with Imputed Quinn Measures}

The above tests were repeated using the aforementioned Quinn measures. Table A-1 shows the results for the regressions using the linearly interpolated Quinn measures (“pseudo-Quinn”). Some similarities between this set of results and the previous one with the full sample are apparent; financial openness appears to have an effect on private credit development (column 2) and the development of equity market activity (column 4). As indicated by the results of the basic regressions with LDC and EMG subsamples in Table A-2, the similarity still holds for the subsamples of LDC and EMG, though the difference is not as marked as it was using the basic model. The link between financial openness and financial development exists for private credit only with the EMG subsample, and the link is somewhat stronger for equity market development with the EMG subsample.

\footnotetext{
${ }^{19}$ Following the debates in the finance-growth literature that regression results in this type of analysis can be highly sensitive to model specifications (Klein and Olivei (2001)), we also implemented fixed effects regressions (results not reported). In these estimates, the statistical significance of the financial openness variable remained for private credit (as it did for LDC and EMG subsamples). However, it largely disappears in the specifications for equity market development indicators. This outcome is unsurprising, as the country fixed effects are highly correlated with the financial openness of an individual country. While it has been argued that fixed effects regressions allow for heterogeneity among countries, some claim it is not reasonable to employ such regressions because they carry a risk of treating heterogeneity among the countries constant over the sample time period.
} 
Interestingly, the fit of the model (as measured by $\mathrm{R}^{2}$ ) is roughly the same regardless whether the $K A O P E N$ or the pseudo-Quinn variable is used.

The regression results based on the two indicators of financial openness are not directly comparable, as the KAOPEN results pertain to a sample encompassing 105 countries, while the pseudo-Quinn results are for a sample of 59 countries (for which actual Quinn data exist so that linear extrapolation is feasible). ${ }^{20}$ However, if we restrict the samples to be the same, one finds that the previously identified pattern of results remains in place.

\subsubsection{Analysis with Instrumental Variables}

In order to investigate whether simultaneity is a problem, two stage least squares is implemented, using the government budget balance and current account balance as instrumental variables. The rationale for using these two variables follows from the findings of Grilli and Milesi-Ferretti (1995). Using $A R E A E R$ 's $k_{l}, k_{2}$, and $k_{3}$ variables as the proxy for the intensity of capital controls, they showed that multiple exchange rate practices $\left(k_{l}\right)$, capital controls in the narrow sense (i.e., $k_{3}$ ), and current account $\left(k_{2}\right)$ are empirically linked to higher rates of inflation, a higher share of seigniorage in total taxes, and lower real interest rates. Furthermore, capital controls tend to be implemented in countries where government consumption as a share of GDP is relatively large and the economy is more closed to trade. They conjecture the statistical relationship between capital controls and lower real interest rates is capturing other forms of government-imposed distortions such as financial repression. ${ }^{21}$ Grilli and Milesi-Ferretti's finding implies that capital controls appear to have strong fiscal implications, i.e., countries with a less developed tax system tend to implement capital controls as the source of government revenue as well as the remedy to capital flows caused by the inflation-driven distortions in the financial markets.

More recently, Johnson and Tamirisa (1998) investigated the empirical determinants of capital controls. Their analysis is innovative in that they used the newly created disaggregate components of capital controls publicized in the AREAER. They tested their theoretical prediction that capital controls may be motivated by (1) balance of payments concerns, (2) macroeconomic

\footnotetext{
${ }^{20}$ See Appendix 2 for an explanation of the linear extrapolation methodology employed to obtain the pseudo-Quinn variable. The countries for which Quinn reports figures for are indicated in the country list (with a superscript c).

${ }^{21}$ Grilli and Milesi-Ferretti also found that the less independent the central bank is, the more likely capital controls are to be imposed. This result is also in line with higher real interest rates and the government's tendency to rely
} 
management, (3) infant industry policy toward underdeveloped financial markets and regulatory systems (the stage of development of the financial system), (4) prudential policy by the government to avoid financial (banking) crisis, and (5) other reasons. Broadly speaking, their finding suggested that countries tend to implement capital controls, the more prevalent the balance of payments concerns are, ${ }^{22}$ the higher real interest rates and real exchange rates, ${ }^{23}$ and the larger the size of the government deficit as a share of GDP.

Following these findings, we use the government budget surplus to GDP ratio $(G S U R)$ and current account balance ratio (CURRENT) as instruments. Regional dummies are also included in order to capture regional differences. In order to minimize the possibility of two-way causality, both variables are lagged.

As a preliminary analysis, the following regression is estimated using the annual data

(4) $K A O P E N_{t}^{i}=\varphi_{0}+\varphi_{1} G S U R_{t-1}^{i}+\varphi_{2} C U R R E N T_{t-1}^{i}+$ region $+\eta_{t}^{i}$

The resulting estimates of both $\varphi_{1}$ and $\varphi_{2}$ are statistically significant with theoretically predicted signs, i.e., $\varphi_{1}, \varphi_{2}>0 .^{24}$

Tables 5 and 6 report the results of the regressions instrumented with the one period lagged variables for government budget balance and current account balance $\left(G S U R_{t-6}\right.$ and $C U R R E N T_{t-6}$, respectively). In general, the estimated magnitude and statistical significance of the capital openness effect are larger for both the full and sub- sample sets. The most interesting difference from the OLS estimates is that the IV-estimated coefficient for stock market turnover is now quite strong and statistically significant. The subsample of less developing countries presents the strongest results. The coefficient for stock market value traded is much stronger. In contrast to the OLS estimates, the

upon seigniorage revenues, i.e., higher inflation.

${ }^{22}$ They mainly used gross international reserves in months of imports as an indicator to capture the balance of payments situation of countries. The lower gross reserves in months of imports, the higher prevalence of balance of payments concerns are.

${ }_{23}$ This result contrasts with that of Grilli and Milesi-Ferretti. Their theoretical prediction is that countries use capital controls to pursue inconsistent internal and external balances simultaneously such as the case where outflow controls are implemented to avoid nominal currency deprecation pressures without tightening of monetary conditions. When such a threat of currency crisis arises, the real interest rates or real exchange rates tends to be higher.

${ }^{24}$ Among the regional dummies, the estimated coefficients for AFRICA and EUROPE were significantly negative and positive, respectively, suggesting that African countries tend to have higher capital controls, whereas European countries tend to have lower ones. 
coefficients for private credit and stock market turnover are now larger in both magnitude and (typically) statistical significance.

\subsubsection{Outliers, Measurement Errors, and the Financial Bubbles}

Lastly, we examine whether our baseline results are sensitive to outliers. Concerns about the impact of outliers flows from two issues. First, in addition to the usual measurement error present in macroeconomic data, it is likely that the data for financial development is subject to even greater measurement errors. Second, these financial development indicators may unintentionally capture financial bubbles. The use of five year changes may serve to mitigate this concern, although it cannot completely address it. As a point of reference, it is useful to note that in many studies of lending booms as financial crises indicators, changes in lending over a shorter window, of between 2 to 4 years are, often used (Corsetti, Pesenti, and Roubini (1998); Chinn, Dooley and Shrestha (1999); Kaminsky, Linzodo and Reihart (1998); Sachs, Tornell and Velasco (1996)). Nonetheless, we investigate whether the regression results are being distorted by data outliers. In order to conserve space, we merely summarize the results and our observation below.

First, using the original annual data, we exclude the observations of financial development variables if their annual growth rates are larger than two standard deviations away from the mean, and re-estimate the same sets of regressions. ${ }^{25}$ The exclusion of outliers shrank the observation size by a relatively small degree, about $3-11 \%$, and hardly affects the regression results from the baseline cases. The same exercise is then repeated, but increasing the range of outlier exclusion by dropping the observations if their annual growth rates are larger than one standard deviation away from the mean. This exclusion shrinks the sample size of the full or sub- sample five year panel sets by about $13-19 \%$. Interestingly, in most cases, the estimated coefficients became slightly larger compared to the baseline cases, but their standard errors remained about the same or increased slightly. The estimates using the liquid liabilities measure of financial development in the full sample are now statistically significant at the $2 \%$ of significance level, whereas in the baseline regressions they were only marginally significant. Except for that of stock market capitalization, estimates of the effect of financial openness rose slightly in both magnitude and statistical significance. Hence, one may safely conclude that outliers do not drive the results we have obtained.

${ }^{25}$ Since we are dealing with a set of non-overlapping five year panels, in essence the only data for 1977, 1982, 1987, 1992, and 1997 are affected by the removal of outliers. 


\section{The Interaction of Financial Development and Legal Factors}

\subsection{Overview}

The previous analysis carries a risk of treating the behavior of countries at different stages of institutional development as the same when doing so is inappropriate. In this section, we relax this assumption and examine the implications of conditioning on legal and institutional features.

Legal foundations and institutions governing financial transactions are especially important for the development of the financial system. In the economies where the legal system does not clearly define property rights or guarantee the enforcement of contracts, the incentives for loan activities can be limited. Legal protections for creditors and the level of credibility and transparency of accounting rules are also likely to affect economic agents' financial decisions. ${ }^{26}$

La Porta, Lopez-de-Silanes, Shleifer, and Vishny (hereafter LLSV, 1998) demonstrate that the national legal origin (whether English, French, German, or Scandinavian) strongly affects the legal and regulatory environment in financial transactions and explains cross-country differences in financial development. Basing their dataset partly on the data presented in LLSV, Levine, Loayza, and Beck (2000) investigate whether the level of legal and regulatory determinants of financial development influences the development financial intermediary sector. ${ }^{27}$ They find a positive link between cross-country differences in the legal and regulatory environment and those in the level of financial intermediary development.

In their investigation on the correlation between capital account liberalization and growth, Arteta, Eichengreen and Wyplosz (2001) also examine whether legal/institutional development influences the effectiveness of capital account liberalization on growth. ${ }^{28}$ Their cross-country investigation reports some evidence that the effect of capital account liberalization on economic growth varies with the degree of legal/institutional development.

In this section, our capital openness index is interacted with variables of legal/institutional development to determine whether the level of legal/institutional development influences the impact of financial openness.

\footnotetext{
${ }^{26}$ For a general discussion on the importance of legal and institutional foundations for financial development, see Beim and Calomiris (2001).

${ }^{27}$ The main focus in their study is to investigate whether financial intermediary development leads to economic growth. They find a positive link between the two.

28 They use the (unprocessed) Quinn index for the measurement of capital account openness.
} 


\subsection{Data on Legal/Institutional Development}

For the variables depicting legal/institutional development, we directly use the variables from LLSV. Specifically, the variables CREDITOR, ENFORCE, SHRIGHTS, ACCOUNT, and LEGAL are employed. CREDITOR refers to the level of creditor protection; a higher CREDITOR indicates more legal protections for creditors. ENFORCE is the index of the effectiveness of the legal system in enforcing contracts, whereas SHRIGHTS is the index of the extent of shareholder protection, and ACCOUNT of the comprehensiveness of company reports. LEGAL is the first standardized principal component of CREDITOR, ENFORCE, SHRIGHTS, and ACCOUNT, and, therefore, depicts the overall development of the legal system governing financial transactions. See the Appendix 1 for more details.

Before discussing the results incorporating these institutional variables, the following two observations must be made. The first pertains to the temporal nature of these institutional variables. Although we have used the panel data on financial development and financial openness measures in the previous section, the data on legal/institutional development are cross-sectional in nature, i.e., they are time-invariant. However, the inclusion of these time-invariant factors should not pose a substantial problem for our analysis, since these characteristics, such as creditor protection, contract enforcement, shareholder protection, and accounting standards, are likely to change only very slowly. Our focus is mainly on the effect of financial openness on financial development, but not the effect of legal/institutional development per se. In other words, rather than shedding light on how the development of institutions and legal systems affects financial development, we examine how the effect of financial openness changes depending upon the "environment" of institutions and legal systems. Therefore, time-variance of legal/institutional variables is not crucial to our study.

The second issue is sample size. In section 2, the panel encompassed 105 countries. In contrast, the data set based on LLSV spans less than 50 countries. $^{29}$ While there is minimal impact regarding coverage of the industrialized countries, the size of the LDC sample is substantially reduced. Consequently, our LDC sample in this portion of the analysis becomes essentially the

\footnotetext{
${ }^{29}$ More specifically, the data set contains LEGAL data for 37 countries, CREDITOR for 44 countries, ENFORCE
} for 46 countries, SHRIGHTS for 46 countries, and ACCOUNT for 38 countries. 
emerging market group previously defined..$^{30}$ Hence, we create a new subset titled the "LDC/EMG" category.

\subsection{Empirical Results}

At this point, regressions of financial development measures on financial openness, augmented with the legal/institutional variables are estimated. The specification is:

(5) $F D_{t}^{i}-F D_{t-5}^{i}=\gamma_{0}+\rho F D_{t-5}^{i}+\gamma_{1} K A O P E N_{t-5}^{i}+\gamma_{2} L^{i}+\gamma_{3}\left(L^{i} \times K A O P E N_{t-5}^{i}\right)+X_{t-5}^{i} \Gamma+u_{t}^{i}$

where $L^{i}$ denotes a legal/institutional variable.

Table 7 reports the results of these regressions for the full sample (columns 1 through 5) and the LDC/EMG subsample (columns 6 through 10). There are two differences compared to the previous tables: the level term for legal/institutional development (LEGAL) and the interaction term between legal/institutional development and financial openness were added to the right hand side of the regression equation (rows 2 and 3 , respectively), and the measure of new equity issued is dropped in the table because of the lack of observations.

While private credit and stock market value traded, both of which were strongly significant in the baseline test, preserved statistical significance with the $10 \%$ level, Table 7 shows that the development of legal/institutional environment individually (i.e., not interacted with financial openness) is associated with the development of private credit, stock market capitalization, and stock market value traded in the full sample. The result for stock market value traded shows that the coefficient for the interactive term between legal environment and financial openness, that is, if it is coupled with a highly developed legal environment, capital liberalization can lead to a further development of stock market activities. These characteristics are not apparent in the LDC/EMG sample, except perhaps for the relationship between legal development and stock market capitalization and stock market value traded (row 2 in columns 8 and 9). Given these results, one might reasonably conclude that in countries with a relatively strong legal institutions, private credit can develop and the size of stock markets tend to be larger in terms of both size and activeness, and also that both private credit and stock market value traded can grow with capital liberalization, but

\footnotetext{
30 The LLSV cross-sectional data set used for this paper includes only three countries which are not either
} industrialized or emerging market countries by our definition. 
with the latter developing even further if capital liberalization is coupled with a highly developed legal environment. However, there is weak evidence for less developed/emerging market countries.

Table 8 reports results disaggregating the $L E G A L$ index into its components. $L E G A L$ is the first standardized principle component of CREDIT, ENFORCE, SHRIGHTS, and ACCOUNT, so using these variables individually as the institutional variables interacted with the financial openness index allows one to isolate the component-specific effects. For brevity, Table 8 reports only the coefficients for the financial openness variable, the level term for legal/institutional development (LEGAL), and the interaction term between financial openness and legal/institutional development.

While creditor protection and the level of enforcement do not seem to have any noticeable effect on financial development individually or interactively in both full and LDC/EMG samples (except for stock market value traded), shareholder protection and accounting standards do seem to have an effect on both bank credit and equity market development. The level of SHRIGHTS appears to contribute to growth in stock market capitalization in both full and LDC/EMG samples. Although financial openness alone does not seem to affect stock market capitalization, if it is coupled with a higher level of shareholder protection, it has a marginal effect on the growth rate of stock market capitalization in emerging market countries. The results for stock market value traded are more positive. For both full and LDC/EMG samples, financial openness alone appears to have a negative effect, if any, on equity market development, but if it is implemented in countries where more shareholder protection is guaranteed, it significantly contributes to the development of the market. This effect of the interaction between shareholder protection and financial openness appears for stock market turnover in the LDC/EMG subsample as well. The marginal effect of interaction between capital openness and legal development is also found for stock market capitalization in LDC/EMG countries. Interestingly, the coefficient for capital openness is negative, if not insignificant, in all emerging market indicators. These results are in line with conventional wisdom that shareholder protection is essential for equity market development, and especially important for LDC/EMG countries.

The results with $A C C O U N T$ are stronger, especially for less developed countries. Among the LDC/EMG countries, the coefficient for the interactive term is significant for both bank credit indicators ([6] and [7]) and for stock market capitalization (and marginally for stock market value traded). For all of these indicators of financial development, the estimate for financial openness is negative, and statistically significant (except for stock market turnover), suggesting that financial 
liberalization alone may cause a negative, or null at best, effect on financial development. The level itself of accounting standards is of course crucial for financial development (the level term has a significantly positive coefficient in columns 7 through 10 ), and it can also compensate the possible negative impact of financial liberalization.

The results with a statistically significant coefficient on the interaction term suggest that while financial liberalization alone may have a zero, or even negative, impact on the development of the financial system, when combined with a well-developed legal system or institutions, it may well serve to stimulate financial development.

\section{Concluding Remarks}

This study has reported the results of an exhaustive analysis of the empirical evidence regarding the relationship between financial openness and financial development. Our first key finding is that if one measures the level of financial development in terms of private credit creation and stock market value traded, there appears to be a strong relationship between the extent of capital controls and financial development. This finding holds for less developed countries in terms of stock market value traded, and even more so for emerging market countries. In this latter group, the linkage is particularly strong for private credit creation, stock market value traded, and stock market turnover.

These results are robust to the presence of outliers in the data, and simultaneity. Indeed, if financial openness is instrumented with the level of government surplus and current account balance, the above findings appear to be even stronger.

Perhaps most importantly, we econometrically verify the widely held belief that financial systems with a higher degree of legal/institutional development on average benefit more from financial liberalization than those with a lower one. In this sense, our results are in line with conventional wisdom. However, the positive effect of legal/institutional development seems to flow primarily from the degree of shareholder protection and accounting standards. That is, the liberalization of capital controls appears to have the largest effect on financial development when these indices are higher. Hence, we add to this perspective by identifying the dimensions of legal protections that are most strongly associated with rapid financial development in the wake of financial opening. 


\section{References}

Aizenman, Joshua (2002), "Financial Opening: Evidence and Policy Options," NBER Working Paper No. 8900 (April).

Arteta, Carlos, Barry Eichengreen and Charles Wyplosz (2001), "When does capital account liberalization help more than it hurts?" NBER Working Paper No. 8414 (August).

Beck, Thorsten, Asli Demirgüc-Kunt, and Ross Levine (2000), "A new database on financial development and structure," Policy Research Paper No. 2147 (Washington, D.C.: World Bank).

Beim, David, and Charles W. Calomiris (2001), Emerging Financial Markets, (New York: McGraw Hill).

Bekaert, Geert, Campbell R. Harvey, and Christian Lundblad (2000), "Emerging Equity Market and Economic Development," NBER Working Paper No. 7763 (April).

Chari, Anusha and Peter Blair Henry (2002), "Capital Account Liberalization: Allocative Efficiency or Animal Spirits," NBER Working Paper No. 8908 (April).

Chinn, Menzie (2001), "The Compatibility of Capital Controls and Financial Development: A Selective Survey and Empirical Evidence," forthcoming in P. Drysdale and G. DeBrouwer (editors), Future Financial Arrangements in East Asia (Routledge).

Chinn, Menzie, Michael P. Dooley and Sona Shrestha (1999), "Latin America and East Asia in the Context of an Insurance Model of Currency Crises," Journal of International Money and Finance 18(4) (August): 659-681.

Corsetti, Giancarlo, Paolo Pesenti, and Nouriel Roubini (1998), "Paper Tigers? A Preliminary Assessment of the Asian Crisis. NBER Working Paper No. 6783 (November).

De Gregorio, José (1998), "Financial Integration, Financial Development and Economic Growth," mimeo (Department of Industrial Engineering, Universidad de Chile, July).

Dooley, Michael (1996), "A Survey of Literature on Controls of International Capital Transactions," IMF Staff Papers 43(4) (December): $639-87$.

Edison, Hali J., Michael W. Klein, Luca Ricci, and Torsten Sløk, (2002), "Capital Account Liberalization and Economic Performance: A Review of the Literature," mimeo (Washington, D.C.: IMF, May).

Edison, Hali J. and Francis E. Warnock (2001), "A simple measure of the intensity of capital controls," International Finance Discussion Paper \#708 (Washington, D.C.: Board of Governors of the Federal Reserve System, September). 
Edwards, Sebastian (2001), "Capital Mobility and Economic Performance: Are Emerging Economies Different?” NBER Working Paper No. 8076 (January).

(1999), "How Effective are Capital Controls?" Journal of Economic Perspectives 13(4) (Fall): 65-84.

(1998), "Capital Flows, Real Exchange Rates, and Capital Controls: Some Latin American Experiences," NBER Working Paper No. 6800 (November).

Grilli, Vittorio and Gian Maria Milesi-Ferretti (1995), "Economic Effects and Structural Determinants of Capital Controls," IMF Staff Papers 42(3) (September): 517 - 51.

Henry, Peter Blair (2000), "Stock Market Liberalization, Economic Reform and Emerging Market Equity Prices," Journal of Finance 55(2): 529-564.

Herring, Richard J. and Nathporn Chatusripitak (2000), "The Case of the Missing Market: The Bond Market and Why It Matters for Financial Development," paper prepared for the ADB/Wharton seminar on "Financial Structure for Sustainable Development in Post-Crisis Asia," Tokyo, May 26,2000 .

International Monetary Fund (2001), World Economic Outlook (Washington, D.C.: IMF, September).

Johnston, R. Barry and Natalia T. Tamirisa (1998), "Why Do Countries Use Capital Controls?" IMF Working Paper WP/98/181 (Washington, D.C.: IMF, December).

Kaminsky, Graciela, Saul Lizondo, Carmen M. Reinhart (1998), "Leading Indicators of Currency Crises," IMF Staff Papers 45(1): 1-48.

Klein, Michael and Giovanni Olivei (2001), "Capital Account Liberalization, Financial Depth and Economic Growth," mimeo (Medford, MA: Tufts).

Kletzer, Kenneth and Ashoka Mody (2000), "Will Self-Protection Policies Safeguard Emerging Markets from Crises?" Managing Financial and Corporate Distress : Lessons from Asia, in Charles Adams, Robert E. Litan, and Michael Pomerleano (editors) (Washington, D.C. : Brookings Institution).

La Porta, Rafael, Florencio Lopez-de-Silanes, Andrei Shleifer and Robert W. Vishny (1998), "Law and Finance," Journal of Political Economy, 106(6): 1113 - 1155.

Leahy, Michael, S. Schich, G. Wehinger, F. Pelgrin, and T. Thorgeirsson (2001), "Contributions of financial systems to growth in OECD countries," OECD Economic Department Working Papers No. 280 .

Levine, Ross, Norman Loayza and Thorsten Beck (2000), "Financial intermediation and growth: Causality and causes", Journal of Monetary Economics 46: 31-77. 
Levine, Ross and Sara Zervos (1998), "Stock Markets, Banks, and Economic Growth," American Economic Review 88(3): 537-558.

Levine, Ross and Sara Zervos (1995), "Capital control liberalization and stock market development," mimeo (Washington, D.C.: World Bank).

Neely, Christopher (1999), "An Introduction to Capital Controls," Review, Federal Bank of St. Louis, November/December.

Quinn, Dennis (1997), "The correlates of change in international financial regulation," American Political Science Review 91(3): 531-551.

Quinn, Dennis, A. Maria Toyoda and Carla Inclan (2002), "Does Capital Account Liberalization Lead to Economic Growth?: An Empirical Investigation" mimeo (Washington, D.C.: Georgetown University).

Sachs, Jeffrey, Aaron Tornell, and Andres Velasco (1996), "Financial Crises in Emerging Markets: The Lessons from 1995" NBER Working Paper No. 5576 (May).

Spiegel, Mark (2001), "Financial development and growth: Are the APEC nations unique?" Pacific Basin Working Papers PB01-04 (Federal Reserve Bank of San Francisco, June). 


\section{Appendix 1: Data Definition and Sources}

Key to abbreviations:

BKL: Beck, Kunt, and Levine (2000).

IFS: IMF, International Financial Statistics.

LLSV: La Porta, Lopez-de-Silanes, Shleifer, and Vishny (1998)

Mody: Personal communication from Ashok Mody, data based on AREAER

Quinn: Personal communication from Dennis Quinn.

WDI: World Bank, World Development Indicators.

\section{$\underline{\text { Macroeconomic Indicators }}$}

ry - GDP, real, local currency, units (line 99b), IFS

ny - GDP, nominal, local currency, units (99b), IFS

m1 - M1, Stock End of Period, units (34), IFS

qm - Quasi-money; M2, units (35), IFS

mqm - Money plus Quasi-money, units (M1 + M2), IFS

sprdl - Spread between average deposit and lending rates, $\%,(60 p-601), I F S$

current - Current account balance as a ratio to GDP, WDI

opn - openness to trade, (nominal exports plus imports)/nominal GDP

exports $=$ national currency (from national account, 90c), IFS

imports $=$ national currency (from national account, 98c), IFS

rypc $=$ per capital real income in international

PPP, WDI

cpi - Consumer price index (64), IFS

infl - Inflation rate calculated using log

differences of CPIs (64), IFS

gsur - government budget surplus $(+)$ or deficit $(-)$ as a ratio to GDP, WDI

pop - population, $99 \mathrm{z}$, IFS

\section{Regional Dummies}

idc - idc $=1$ if industrialized country, and 0 , otherwise (See the list of countries)

emg - emg $=1$ if emerging market country, and 0 , otherwise (See the list of countries)

asia - dummy for Asian countries africa-dummy for African countries

westhem - dummy for the countries in the west hemisphere

europe - dummy for European countries

mideast - dummy for Middle East countries

\section{Financial Development Indicators}

lly - Liquid Liability to GDP (LLY), currency

demand and interest-bearing liabilities of banks and other financial intermediaries divided by GDP, BKL, 1970-97.

smkc - stock market capitalization ratio to GDP, BKL, 1970-97

smtv - stock market total value traded to GDP, BKL, 1975-97

smto - stock market turn over ratio, BKL, 1975-97

pvbm - private bond market capitalization to GDP, BKL, 1975-97

pbbm - public bond market capitalization to GDP ratio, BKL, 1975-97

eqty - equity issues to GDP, BKL, 1975-97

Itpd - long-term private debt issues to GDP, BKL, 1975-97

bts - Deposit Money Bank Assets to Total

Financial Assets, BKL, 1970 - 1997

dmcb - Deposit Money vs. Central Bank

Assets, BKL, 1970 - 97

dmgdp - Deposit Money Bank Assets to GDP, BKL, 1970 - 97

pcgdp - Private Credit by Deposit Money

Banks to GDP, BKL, 1970 - 97

$\mathbf{m} 2 \mathbf{y}$ - Ratio of M2 to nominal GDP, IFS,1970-99) 


\section{Capital Controls Indicators}

$\mathbf{k}_{\mathbf{1}}$ - multiple exchange rates, Mody

$\mathbf{k}_{\mathbf{2}}$ - restrictions on CA trans, Mody

$\mathbf{k}_{3}$ - restrictions on KA trans, Mody

$\mathbf{k}_{\mathbf{4}}$ - surrender of exports proceeds, Mody

SHAREk $_{3}$ - Share of a five-year period, the observed year and the last four years, when the capital account was open. Authors' calculations KAOPEN - index for openness to capital account transactions. The first standardized principal components of $\mathrm{k}_{1}, \mathrm{k}_{2}, \mathrm{SHAREk}_{3}$, and $\mathrm{k}_{4}$. Authors' calculations.

blmkpr - black market premium, World Bank openn - Quinn financial liberalization indicator, Quinn.

\section{$\underline{\text { Legal Institutional Variables }}$}

legal - legal index, the first component of credit, enforce, shrights, and account, cross-sectional for 37 countries, LLSV

credit - index of creditor protection, composed of the variables which incorporate the automatic stay proposition on the assets of a failing firm

("noauto"); the continuation of the old managers in a reorganization process ("manages"); restrictions for going into reorganization ("restorg"); and the seniority system of secured creditors ("secured1"), cross-sectional for 44countries, LLSV

enforce - index of the degree of law enforcement. Specifically, it is the average of "judsys" (efficiency of the judicial system), "rulelaw" (rule of law), "riskEx" (risk of expropriation), and "contrepu" (risk of contract repudiation), average over period 1982 - 1995, cross-sectional for 46 countries, LLSV

shrights - the sum of "oneshvt" (one share-one vote), "bymail" (proxy by mail allowed),

"noblock" (shares not blocked before meeting), "comulvt" (cumulative voting/proportional representation), "oppdmnty" (oppressed minority), "premprt" (preemptive right to new issues), and "esm" (\% of share capital to call an emergency shareholder meeting $<10 \%$ ), cross-sectional for 46 countries, LLSV account - index of transparency and comprehensiveness of companies' (accounting) reports, based on data in 1990, cross-sectional for 38 countries, LLSV

corrupt - corruption index, average over period 1982 - 1997, (International Country Risk Guide)

cn - country code (1-105), see the country list 


\section{Country list (105 countries)}

\begin{tabular}{|c|c|c|c|c|c|}
\hline 1 & ARG & Argentina ${ }^{b, c}$ & 56 & LKA & Sri Lanka ${ }^{b, c}$ \\
\hline 2 & AUS & Australia $^{\mathrm{a}, \mathrm{c}}$ & 57 & LSO & Lesotho \\
\hline 3 & AUT & Austria ${ }^{\mathrm{a}, \mathrm{c}}$ & 58 & MAR & Morocco $^{\mathrm{b}, \mathrm{c}}$ \\
\hline 4 & BDI & Burundi & 59 & MDG & Madagascar \\
\hline 5 & BEL & Belgium $^{\text {a, } c}$ & 60 & MEX & Mexico $^{b, c}$ \\
\hline 6 & BEN & Benin & 61 & MLI & Mali \\
\hline 7 & BFA & Burkina Faso & 62 & MLT & Malta \\
\hline 8 & BGD & Bangladesh $^{\mathrm{b}}$ & 63 & MRT & Mauritania \\
\hline 9 & BHR & Bahrain & 64 & MUS & Mauritius \\
\hline 10 & BHS & Bahamas, The & 65 & MWI & Malawi \\
\hline 11 & BLZ & Belize & 66 & MYS & Malaysia $^{\mathrm{b}, \mathrm{c}}$ \\
\hline 12 & BOL & Bolivia $^{c}$ & 67 & NER & Niger \\
\hline 13 & BRA & Brazil $^{\mathrm{b}, \mathrm{c}}$ & 68 & NGA & Nigeria ${ }^{b, c}$ \\
\hline 14 & BRB & Barbados & 69 & NIC & Nicaragua $^{\mathrm{c}}$ \\
\hline 15 & BWA & Botswana & 70 & NLD & Netherlands a, c \\
\hline 16 & CAF & Central African Republic & 71 & NOR & Norway ${ }^{\text {a, c }}$ \\
\hline 17 & CAN & Canada ${ }^{a, c}$ & 72 & NPL & Nepal \\
\hline 18 & $\mathrm{CHE}$ & Switzerland ${ }^{\mathrm{a}, \mathrm{c}}$ & 73 & NZL & New Zealand ${ }^{a, c}$ \\
\hline 19 & CHL & Chile $^{\mathrm{b}, \mathrm{c}}$ & 74 & OMN & Oman \\
\hline 20 & CIV & Cote d'Ivoire ${ }^{\mathrm{b}}$ & 75 & PAK & Pakistan b, c \\
\hline 21 & CMR & Cameroon & 76 & PAN & Panama $^{\mathrm{c}}$ \\
\hline 22 & $\mathrm{COG}$ & Congo, Rep. & 77 & PER & Peru $^{c}$ \\
\hline 23 & $\mathrm{COL}$ & Colombia ${ }^{b, c}$ & 78 & PHL & Philippines ${ }^{b, c}$ \\
\hline 24 & CRI & Costa Rica $^{\mathrm{c}}$ & 79 & PNG & Papua New Guinea \\
\hline 25 & CYP & Cyprus & 80 & PRT & Portugal ${ }^{\text {a, b, c }}$ \\
\hline 26 & DNK & Denmark $^{\text {a, c }}$ & 81 & PRY & Paraguay ${ }^{c}$ \\
\hline 27 & DOM & Dominican Republic $^{c}$ & 82 & RWA & Rwanda \\
\hline 28 & DZA & Algeria & 83 & SAU & Saudi Arabia \\
\hline 29 & ECU & Ecuador $^{\mathrm{c}}$ & 84 & SEN & Senegal \\
\hline 30 & EGY & Egypt, Arab Rep. ${ }^{b, c}$ & 85 & SGP & Singapore $^{c}$ \\
\hline 31 & ESP & Spain ${ }^{a, c}$ & 86 & SLE & Sierra Leone \\
\hline 32 & FIN & Finland ${ }^{\text {a, }} \mathrm{c}$ & 87 & SLV & El Salvador ${ }^{c}$ \\
\hline 33 & FJI & Fiji & 88 & SWE & Sweden ${ }^{\mathrm{a}, \mathrm{c}}$ \\
\hline 34 & FRA & France $^{\mathrm{a}, \mathrm{c}}$ & 89 & SWZ & Swaziland \\
\hline 35 & GAB & Gabon & 90 & SYC & Seychelles \\
\hline 36 & GBR & United Kingdom ${ }^{\text {a, }} \mathrm{c}$ & 91 & SYR & Syrian Arab Republic ${ }^{c}$ \\
\hline 37 & GHA & Ghana $^{c}$ & 92 & TCD & Chad \\
\hline 38 & GMB & Gambia, The & 93 & TGO & Togo \\
\hline 39 & GRC & Greece $^{a, b, c}$ & 94 & THA & Thailand $^{\mathrm{b}, \mathrm{c}}$ \\
\hline 40 & GTM & Guatemala $^{\mathrm{c}}$ & 95 & TTO & Trinidad and Tobago ${ }^{\mathrm{b}}$ \\
\hline 41 & HND & Honduras ${ }^{c}$ & 96 & TUN & Tunisia ${ }^{b, c}$ \\
\hline 42 & HTI & Haiti $^{c}$ & 97 & TUR & Turkey ${ }^{b, c}$ \\
\hline 43 & IDN & Indonesia $^{\mathrm{b}, \mathrm{c}}$ & 98 & TZA & Tanzania \\
\hline 44 & IND & India $^{b, c}$ & 99 & UGA & Uganda \\
\hline 45 & IRL & Ireland ${ }^{\mathrm{a}, \mathrm{c}}$ & 100 & URY & Uruguay $^{c}$ \\
\hline 46 & IRN & Iran, Islamic Rep. ${ }^{\mathrm{c}}$ & 101 & USA & United States ${ }^{a, c}$ \\
\hline 47 & ISL & Iceland & 102 & VEN & Venezuela ${ }^{\mathrm{b}, \mathrm{c}}$ \\
\hline 48 & ISR & Israel $^{\mathrm{b}, \mathrm{c}}$ & 103 & ZAF & South Africa ${ }^{b, c}$ \\
\hline 49 & ITA & Italy $\mathrm{a}, \mathrm{c}$ & 104 & ZMB & Zambia \\
\hline 50 & JAM & Jamaica $^{b}$ & 105 & ZWE & Zimbabwe $^{\mathrm{b}}$ \\
\hline 51 & JOR & Jordan ${ }^{\mathrm{b}, \mathrm{c}}$ & \multirow{5}{*}{\multicolumn{3}{|c|}{$\begin{array}{l}\text { a - industrialized countries (IDC), } 20 \text { countries } \\
\text { b - emerging market countries (EMG), } 30 \text { countries } \\
\text { (Bekaert, Harvey, and Lundblad (2000)) } \\
c \text { - countries for which Quinn (1997) variables exis }\end{array}$}} \\
\hline 52 & JPN & Japan $^{\mathrm{a}, \mathrm{c}}$ & & & \\
\hline 53 & KEN & Kenya ${ }^{b}$ & & & \\
\hline 54 & KOR & Korea, Rep. ${ }^{\mathrm{b}, \mathrm{c}}$ & & & \\
\hline 55 & KWT & Kuwait & & & \\
\hline
\end{tabular}




\section{Appendix 2: The "Pseudo-Quinn" Variable}

Quinn (1997) calculates a composite measure of financial regulation that ranges from 0 to 14, with 14 representing the least regulated and most open regime. The bulk of the index is based upon Quinn's coding of the qualitative information contained in the various issues of Annual Report on Exchange Restrictions and Exchange Arrangements (AREAER) pertaining to $k_{2}$ and $k_{3}$, augmented by information regarding whether the country in question has entered into international agreements with international organizations such as the OECD and EU.

A complete tabulation for the OECD members exists, but the coverage for the less developed countries is much less extensive; values are reported only for certain years $(1958,1973$, 1982, and 1988). Figure A-1 illustrates the index's behavior for Argentina and for the United States. The lack of observations relating to the developing countries is frustrating as one would be particularly interested in the role of financial liberalization in emerging economies.

As an expedient, we estimate a Quinn measure of financial regulation for the developing countries. The estimation of this "pseudo-Quinn" measure proceeds in the following manner. As a preliminary analysis, we used the entire sample to estimate the following relationship between the Quinn measure and the variables $k_{l}$ through $k_{4}$.

\section{(A-1) $\quad$ Quinn $_{t}^{i}=\theta_{0}+\sum_{j=1}^{4} \theta_{j} k_{j, t}^{i}+v_{t}^{i}$}

When this regression is implemented over the entire sample of industrialized and less developed countries, all the coefficients entering with the expected positive sign, and with statistical significant (the $k_{j}$ variables take a value of one when a control is not in effect, and the Quinn measure takes on a higher value the weaker the restriction ${ }^{31}$ ). This regression is a very blunt instrument to use to estimate the Quinn variable, but remarkably these four variables explain a majority of the variation in the index; the adjusted $R^{2}$ is 0.71 .

One might think that the relationship linking the Quinn measure and capital controls dummy variables differs over groups. One obvious distinction to examine is that between the industrialized and less developed countries. Equation (A-2) was estimated allowing for an intercept shift and differential slope coefficients. The intercept shift is statistically significant, but

\footnotetext{
${ }^{31}$ Recall that the original $k_{j}$ variables took a value of unity when a control is in effect. We reverse the signs of
} 
this may represent the fact that there are no observations on emerging market Quinn indices during the entire 1990's. The only differential slope coefficient that is significant is the capital account $\left(k_{3}\right)$ one, at the 7\% marginal significance level. In order to further improve the performance of this linear imputation, we also included time trend for each country.

$$
\text { (A-2) } \operatorname{Quinn}_{t}^{i}=\theta_{0}+\sum_{j=1}^{4} \theta_{j} k_{j, t}^{i}+\lambda_{1} I D C_{t}^{i}+\lambda_{2} I D C_{t}^{i} \times k_{3}^{i}+\lambda_{3}^{i} \text { time }+v_{t}^{i}
$$

where $I D C^{i}=1$ for developed countries, and $=0$, otherwise

This estimation method increases the adjusted $\mathrm{R}^{2}$ up to 0.92 . Using this method, we estimate the pseudo-Quinn variable. The correlation between the pseudo-Quinn variable and KAOPEN is estimated to be 0.94. Figure A-2 displays the pseudo-Quinn and KAOPEN series for Argentina; clearly the movement of the former is a good proxy for the latter. 
Table 1

Descriptive Statistics

Full Sample, 1977 - 1997

\begin{tabular}{|c|c|c|c|c|c|}
\hline & & Mean & $\begin{array}{l}\text { Average Growth } \\
\text { Rate (\%) }\end{array}$ & $\begin{array}{c}\text { S.D. of Avg. } \\
\text { Growth Rate } \\
(\%)\end{array}$ & $n=$ \\
\hline 1 & $\begin{array}{l}\text { Liquid Liabilities } \\
\text { to GDP Ratio (LLY) }\end{array}$ & 0.4514 & 0.0163 & 0.0205 & 1976 \\
\hline 2 & $\begin{array}{l}\text { Private Credit to } \\
\text { GDP Ratio (PCGDP) }\end{array}$ & 0.3178 & 0.0285 & 0.0396 & 1973 \\
\hline 3 & $\begin{array}{l}\text { M2 to GDP Ratio } \\
\text { (M2Y) }\end{array}$ & 0.4252 & 0.0133 & 0.0226 & 2144 \\
\hline 4 & $\begin{array}{l}\text { Stock Market Capitalization } \\
\text { To GDP Ratio (SMKC) }\end{array}$ & 0.2882 & 0.0587 & 0.1096 & 1015 \\
\hline 5 & $\begin{array}{c}\text { Stock Market Total Value } \\
\text { Traded to GDP Ratio (SMTV) }\end{array}$ & 0.1077 & 0.1530 & 0.4242 & 1063 \\
\hline 6 & $\begin{array}{c}\text { Stock Market Turn Over to GDP } \\
\text { Ratio (SMTO) }\end{array}$ & 0.2968 & 0.0293 & 0.2132 & 1000 \\
\hline 7 & $\begin{array}{l}\text { New Equity Issued to GDP Ratio } \\
\text { (EQTY) }\end{array}$ & 0.0131 & 0.0685 & 0.1782 & 522 \\
\hline 8 & $\mathbf{k}_{1}$ : Multiple Exchange Rates & 0.7897 & 0.0076 & 0.0224 & 2183 \\
\hline 9 & $k_{2}$ : Current Account & 0.5190 & 0.0028 & 0.1313 & 2183 \\
\hline 10 & $\mathbf{k}_{3}$ : Capital Account & 0.2461 & 0.0388 & 0.0600 & 2178 \\
\hline 11 & $\begin{array}{c}\mathbf{k}_{4}: \text { Surrender of Export } \\
\text { Proceeds }\end{array}$ & 0.2525 & 0.0542 & 0.1135 & 2182 \\
\hline 12 & SHAREK $_{3}$ & 0.2402 & 0.0370 & 0.0450 & 2358 \\
\hline 13 & Capital Openness (KAOPEN) & 0.000 & 0.0379 & 0.0917 & 2357 \\
\hline 14 & $\begin{array}{c}\text { Per Capita Income (in PPP) } \\
\text { (RYPC) }\end{array}$ & 5957.99 & 0.0551 & 0.0442 & 2115 \\
\hline 15 & Trade Openness (OPN) & 0.6966 & 0.0042 & 0.0307 & 2187 \\
\hline 16 & Inflation(INFL) & 0.1303 & -0.0171 & 0.1691 & 2022 \\
\hline
\end{tabular}

Notes: Samples periods differ. Mean pertains to the untransformed variable. Growth rates calculated using log differences. Observations of inflation rates in excess of $100 \%$ are dropped from the sample. KAOPEN is the first standardized principal component of SHARE $k_{3}, k_{1}, k_{2}$, and $k_{4}$, each of which is the share of the last five years (including the observed year) when the capital account was open; the non-existence of multiple exchange rates; the openness of the current account; and no obligation of surrender of export proceeds. Since KAOPEN is a series of first principal components, its average is zero. 
Table 2

Correlations of Selected Financial Deepening Measures Full Sample

\begin{tabular}{|c|c|c|c|c|c|}
\hline & LLY & PCGDP & M2Y & SMKC & SMTV \\
\hline $\begin{array}{l}\text { Liquid Liabilities } \\
\text { To GDP Ratio }\end{array}$ & 1 & & & & \\
\hline $\begin{array}{l}\text { Private Credit } \\
\text { To GDP Ratio }\end{array}$ & 0.812 & 1 & & & \\
\hline M2 to GDP Ratio & 0.849 & 0.774 & 1 & & \\
\hline $\begin{array}{c}\text { Stock Market } \\
\text { Capitalization to } \\
\text { GDP Ratio } \\
\text { Stock Market }\end{array}$ & 0.445 & 0.509 & 0.352 & 1 & \\
\hline $\begin{array}{c}\text { Total Value Traded } \\
\text { To GDP Ratio } \\
\end{array}$ & 0.475 & 0.538 & 0.380 & 0.690 & 1 \\
\hline
\end{tabular}

Notes: Correlation coefficients for common samples. 
Table 3

Financial Development and Financial Openness

Full Sample, Five year panels, 1982-97

\begin{tabular}{|c|c|c|c|c|c|c|c|}
\hline & $\begin{array}{l}\text { Pred } \\
\text { sign }\end{array}$ & $\begin{array}{c}\text { Liquid } \\
\text { Liabilities } \\
{[1]}\end{array}$ & $\begin{array}{c}\text { Private } \\
\text { Credit } \\
\text { [2] }\end{array}$ & $\begin{array}{c}\text { Stock Mkt } \\
\text { Capital'n } \\
\text { [3] }\end{array}$ & $\begin{array}{c}\text { Stock Mkt } \\
\text { Total Value } \\
{[4]}\end{array}$ & $\begin{array}{c}\text { Stock Mkt } \\
\text { Turnover } \\
{[5]}\end{array}$ & $\begin{array}{c}\text { Equity } \\
\text { Issued } \\
\text { [6] }\end{array}$ \\
\hline $\begin{array}{l}\text { Financial } \\
\text { Openness [t-5] }\end{array}$ & $(+)$ & $\begin{array}{l}0.0021 \pi \\
(0.0013)\end{array}$ & $\begin{array}{c}0.0034^{* * *} \\
(0.0012)\end{array}$ & $\begin{array}{c}0.0028 \\
(0.0033)\end{array}$ & $\begin{array}{c}0.0063^{* * *} \\
(0.0021)\end{array}$ & $\begin{array}{l}0.0003 \\
(0.0035)\end{array}$ & $\begin{array}{c}0.0002 \\
(0.0003)\end{array}$ \\
\hline $\begin{array}{l}\text { Financial } \\
\text { Deepening [t-5] }\end{array}$ & $(-)$ & $\begin{array}{l}-0.0079 \\
(0.0095)\end{array}$ & $\begin{array}{l}-0.0181 \pi \\
(0.0112)\end{array}$ & $\begin{array}{l}-0.0136 \\
(0.0338)\end{array}$ & $\begin{array}{l}-0.0931^{*} \\
(0.0560)\end{array}$ & $\begin{array}{c}-0.1126^{* * *} \\
(0.0303)\end{array}$ & $\begin{array}{c}-0.0481^{\star \star} \\
(0.0233)\end{array}$ \\
\hline $\begin{array}{l}\text { Per Capita } \\
\text { Income [t-5] }\end{array}$ & $(+)$ & $\begin{array}{l}0.0018 \\
(0.0017)\end{array}$ & $\begin{array}{c}0.0040^{* * *} \\
(0.0016)\end{array}$ & $\begin{array}{c}0.0053 \\
(0.0044)\end{array}$ & $\begin{array}{l}0.0062^{*} \\
(0.0035)\end{array}$ & $\begin{array}{l}0.0170^{\star *} \\
(0.0072)\end{array}$ & $\begin{array}{l}-0.0003 \\
(0.0004)\end{array}$ \\
\hline Inflation [t-5] & $(-)$ & $\begin{array}{l}-0.0075 \\
(0.0084)\end{array}$ & $\begin{array}{c}0.0074 \\
(0.0121)\end{array}$ & $\begin{array}{c}-0.0531^{* * *} \\
(0.0187)\end{array}$ & $\begin{array}{l}-0.0248^{*} \\
(0.0138)\end{array}$ & $\begin{array}{c}0.0063 \\
(0.0519)\end{array}$ & $\begin{array}{l}-0.0018 \pi \\
(0.0012)\end{array}$ \\
\hline $\begin{array}{l}\text { Trade } \\
\text { Openness [t-5] }\end{array}$ & $(+)$ & $\begin{array}{c}0.0039 \\
(0.0036)\end{array}$ & $\begin{array}{l}0.0059^{* *} \\
(0.0029)\end{array}$ & $\begin{array}{l}-0.0199 \\
(0.0173)\end{array}$ & $\begin{array}{c}0.0030 \\
(0.0071)\end{array}$ & $\begin{array}{l}-0.0087 \\
(0.0105)\end{array}$ & $\begin{array}{l}-0.0004 \\
(0.0006)\end{array}$ \\
\hline $\begin{array}{l}\text { R-squared } \\
\text { N } \\
\text { RMSE }\end{array}$ & & $\begin{array}{c}0.05 \\
300 \\
0.022\end{array}$ & $\begin{array}{c}0.12 \\
298 \\
0.022\end{array}$ & $\begin{array}{c}0.20 \\
148 \\
0.044\end{array}$ & $\begin{array}{c}0.26 \\
156 \\
0.036\end{array}$ & $\begin{array}{c}0.33 \\
150 \\
0.066\end{array}$ & $\begin{array}{c}0.12 \\
55 \\
0.003\end{array}$ \\
\hline
\end{tabular}

Notes: Point estimates from OLS, heteroskedasticity robust standard errors in parentheses. Dependent variable is the average annual growth rate over a five year period. Financial openness variable is the first standardized principal component of SHAREk3, k1, k2, and k4, each of which is the share of the last five years (including the observed year) when the capital account was open, the non-existence of multiple exchange rates, the openness of the current account, and no obligation of surrender of export proceeds. $\mathrm{N}$ is the number of observations. RMSE is root mean squared error of the regression. Regressions include fixed time effects (estimates not reported). Observations of inflation rates in excess of $100 \%$ are dropped from the sample. $\left.\mathbb{T}\left({ }^{\star}\right)\left[{ }^{* *}\right]{ }^{* \star *}\right\}$ indicates marginal significance at the $20 \%(10 \%)[5 \%]\{1 \%\}$ level. 


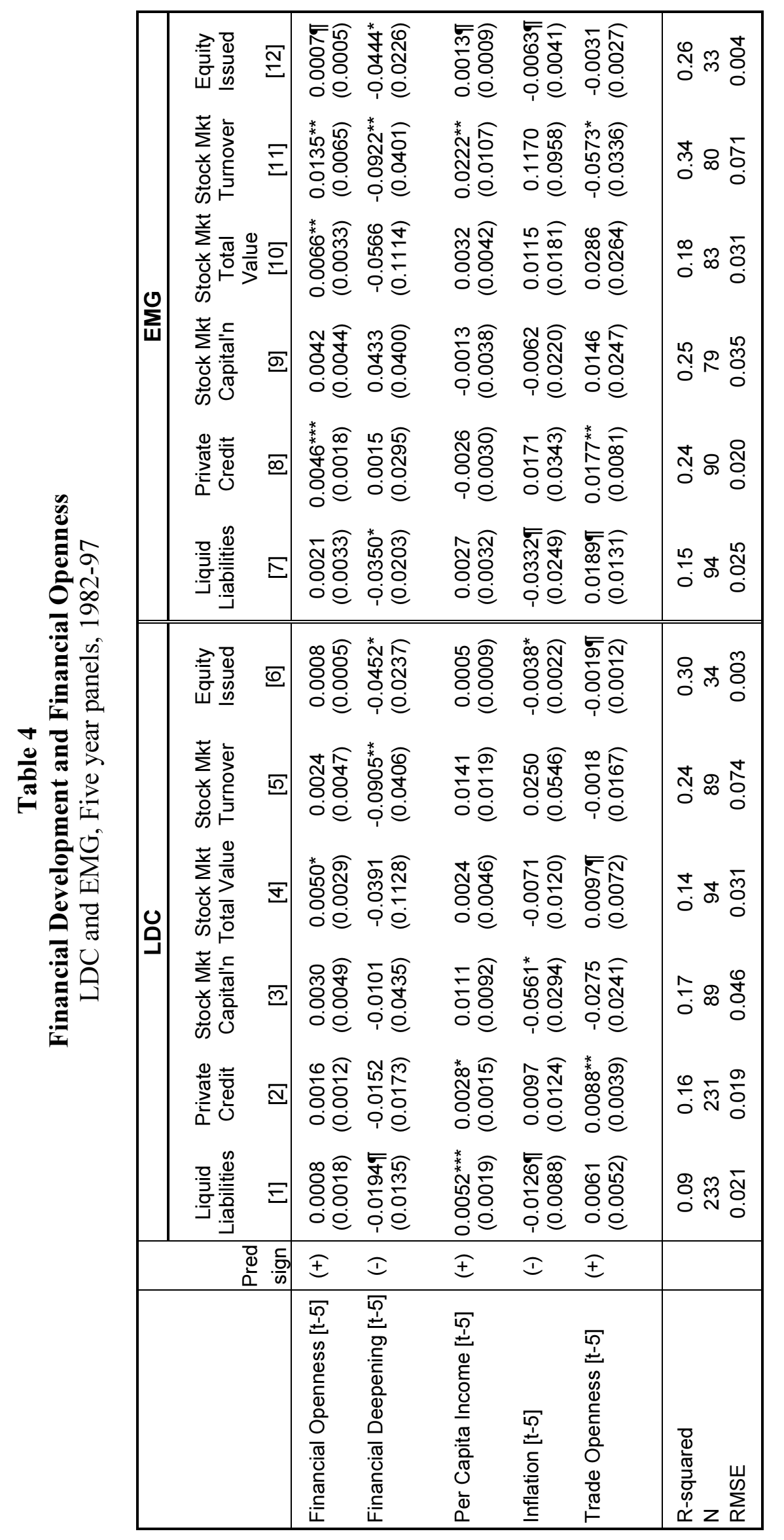

ठั)

苋的的

둬웜잉

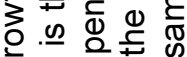

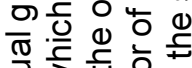

उद् 한

त 0 \%

ब穴

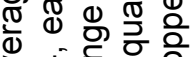

过宁 施。

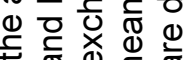

몬

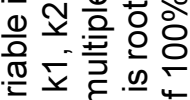

का ल

艺岀过

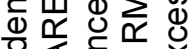

정

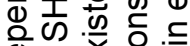

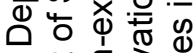

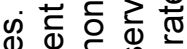

吅

돈 은

ब

증 증은

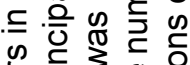

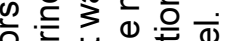

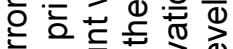

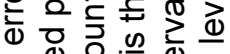

윤

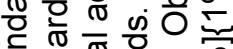

त 응 휴

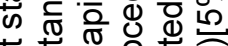

फ

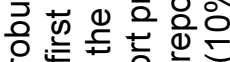

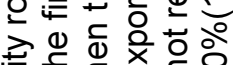

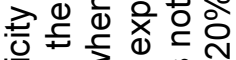

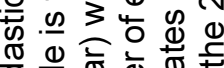

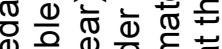

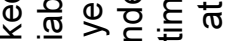

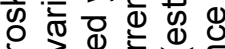

ब

牲

ஸ)

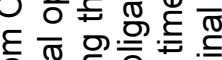

은 증 등응 흥

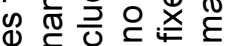

준

둥 的宁至

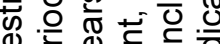

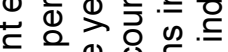

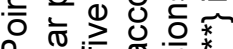

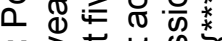

is $>$ 菏

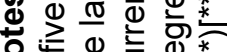

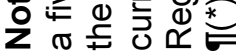




\section{Table 5}

\section{Financial Development and Financial Openness Instrumental Variables Estimation}

Full Sample, Five year panels, 1982-97

\begin{tabular}{|c|c|c|c|c|c|c|c|}
\hline & $\begin{array}{c}\text { Pred } \\
\text { sign }\end{array}$ & \begin{tabular}{|c} 
Liquid \\
Liabilities \\
{$[1]$}
\end{tabular} & $\begin{array}{c}\text { Private } \\
\text { Credit } \\
{[2]}\end{array}$ & $\begin{array}{c}\text { Stock Mkt } \\
\text { Capital'n } \\
{[3]}\end{array}$ & $\begin{array}{c}\text { Stock Mkt } \\
\text { Total Value } \\
{[4]}\end{array}$ & $\begin{array}{c}\text { Stock Mkt } \\
\text { Turnover } \\
{[5]}\end{array}$ & $\begin{array}{c}\text { Equity } \\
\text { Issued } \\
\text { [6] }\end{array}$ \\
\hline $\begin{array}{l}\text { Financial } \\
\text { Openness [t-5] }\end{array}$ & $(+)$ & $\begin{array}{l}0.0099^{* * *} \\
(0.0046)\end{array}$ & $\begin{array}{c}0.0109^{* * *} \\
(0.0040)\end{array}$ & $\begin{array}{c}0.0031 \\
(0.0069)\end{array}$ & $\begin{array}{c}0.0170^{* * *} \\
(0.0051)\end{array}$ & $\begin{array}{l}0.0193^{* *} \\
(0.0081)\end{array}$ & $\begin{array}{c}0.0005 \\
(0.0011)\end{array}$ \\
\hline $\begin{array}{l}\text { Financial } \\
\text { Deepening [t-5] }\end{array}$ & $(-)$ & $\begin{array}{l}-0.0092 \\
(0.0097)\end{array}$ & $\begin{array}{c}-0.0359^{* *} \\
(0.0148)\end{array}$ & $\begin{array}{l}-0.0133 \\
(0.0333)\end{array}$ & $\begin{array}{c}-0.1343^{\star * *} \\
(0.0518)\end{array}$ & $\begin{array}{c}-0.1211^{* * *} \\
(0.0321)\end{array}$ & $\begin{array}{r}-0.0484^{* \star} \\
(0.0228)\end{array}$ \\
\hline $\begin{array}{l}\text { Per Capita } \\
\text { Income [t-5] }\end{array}$ & $(+)$ & $\begin{array}{l}-0.0041 \\
(0.0035)\end{array}$ & $\begin{array}{c}0.0013 \\
(0.0026)\end{array}$ & $\begin{array}{c}0.0042 \\
(0.0066)\end{array}$ & $\begin{array}{l}-0.0010 \\
(0.0054)\end{array}$ & $\begin{array}{l}-0.0017 \\
(0.0105)\end{array}$ & $\begin{array}{l}-0.0006 \\
(0.0010)\end{array}$ \\
\hline Inflation [t-5] & $(-)$ & $\begin{array}{l}-0.0026 \\
(0.0101)\end{array}$ & $\begin{array}{c}0.0016 \\
(0.0145)\end{array}$ & $\begin{array}{c}-0.0571^{* * *} \\
(0.0209)\end{array}$ & $\begin{array}{l}-0.0230 \\
(0.0183)\end{array}$ & $\begin{array}{c}0.0378 \\
(0.0675)\end{array}$ & $\begin{array}{l}-0.0010 \\
(0.0026)\end{array}$ \\
\hline $\begin{array}{l}\text { Trade } \\
\text { Openness [t-5] }\end{array}$ & $(+)$ & $\begin{array}{c}0.0022 \\
(0.0038)\end{array}$ & $\begin{array}{c}0.0038 \\
(0.0041)\end{array}$ & $\begin{array}{l}-0.0219 \\
(0.0173)\end{array}$ & $\begin{array}{l}-0.0008 \\
(0.0076)\end{array}$ & $\begin{array}{l}-0.0168 \mathbb{1} \\
(0.0124)\end{array}$ & $\begin{array}{l}-0.0006 \\
(0.0010)\end{array}$ \\
\hline $\begin{array}{l}\text { R-squared } \\
\text { N } \\
\text { RMSE }\end{array}$ & & $\begin{array}{c}\mathrm{NR}^{2} \\
236 \\
0.024\end{array}$ & $\begin{array}{c}\mathrm{NR}^{2} \\
234 \\
0.024\end{array}$ & $\begin{array}{c}0.23 \\
138 \\
0.044\end{array}$ & $\begin{array}{c}0.19 \\
141 \\
0.040\end{array}$ & $\begin{array}{c}0.25 \\
137 \\
0.073\end{array}$ & $\begin{array}{c}0.10 \\
54 \\
0.003\end{array}$ \\
\hline
\end{tabular}

Notes: Point estimates from 2SLS, with instrumental variables of regional dummies, lagged government budget surplus and current account balance. Heteroskedasticity robust standard errors in parentheses. Dependent variable is the average annual growth rate over a five year period. Financial openness variable is the first standardized principal component of SHAREk3, $\mathrm{k} 1, \mathrm{k} 2$, and $\mathrm{k} 4$, each of which is the share of the last five years (including the observed year) when the capital account was open, the non-existence of multiple exchange rates, the openness of the current account, and no obligation of surrender of export proceeds. $\mathrm{N}$ is the number of observations. RMSE is root mean squared error of the regression. Regressions include fixed time effects (estimates not reported). Observations of inflation rates in excess of $100 \%$ are dropped from the sample. $\left.\mathbb{T}\left({ }^{*}\right)\left[{ }^{* *}\right]{ }^{* * *}\right\}$ indicates marginal significance at the $20 \%(10 \%)[5 \%]\{1 \%\}$ level. "NR" means the R-squared is negative. 


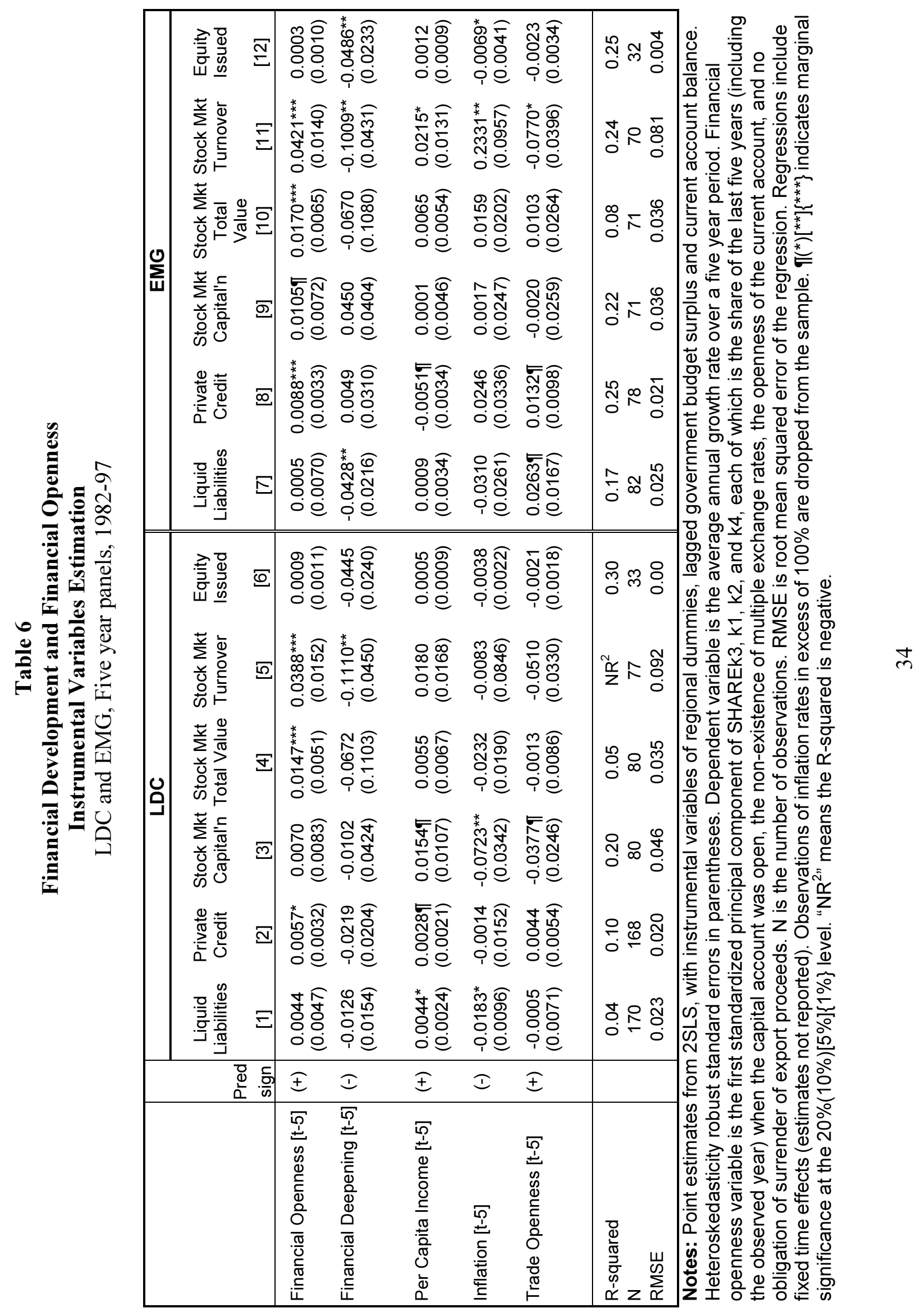




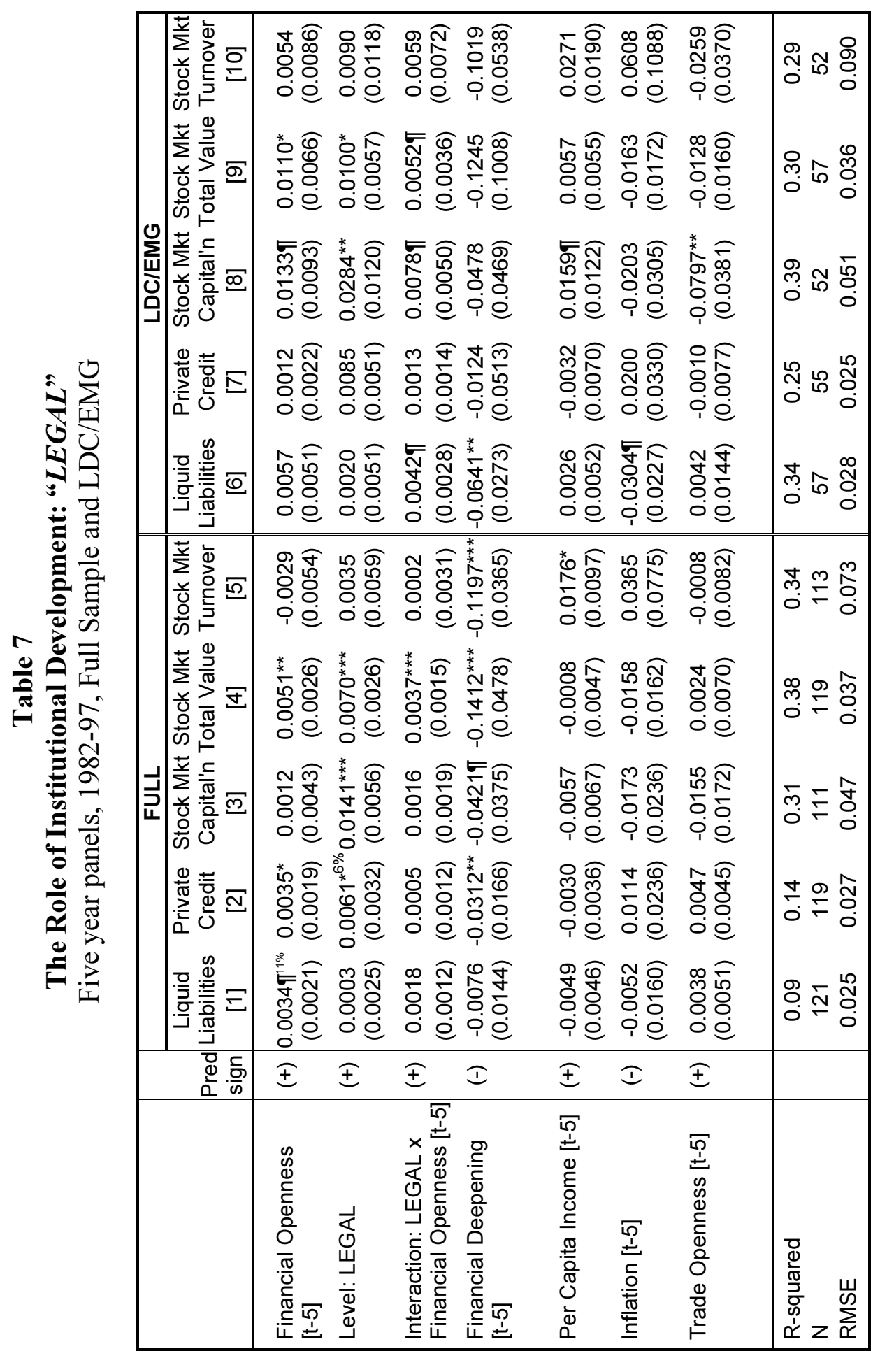

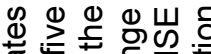

它

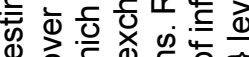

1 0

등 똔

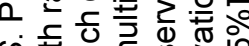

ए

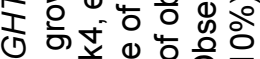

뚜웡

क ट त $\frac{1}{\omega}$ है कें

임

ত

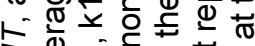

\

○

U Ð

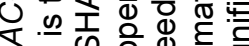

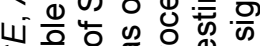

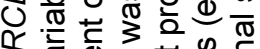

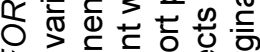

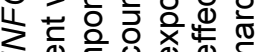

Uิ

ชิ

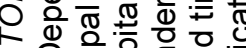

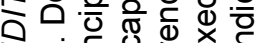

यi

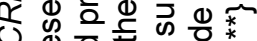

4⿻

능 흔 돈

ब元 $\frac{0}{0} 3$

응 둥 응 응

舟

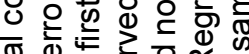

$\bar{\sigma}$ ब证

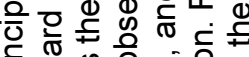

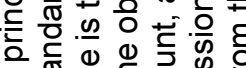

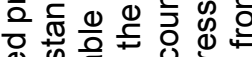

Nㅡㄴ

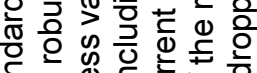

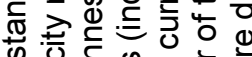

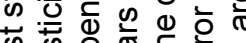

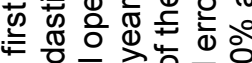

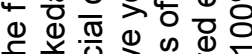

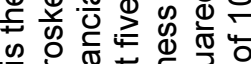

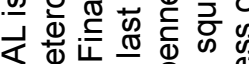

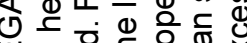

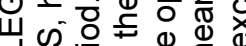

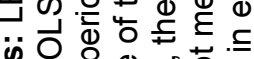

ฏ 은

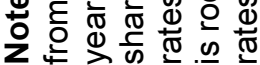




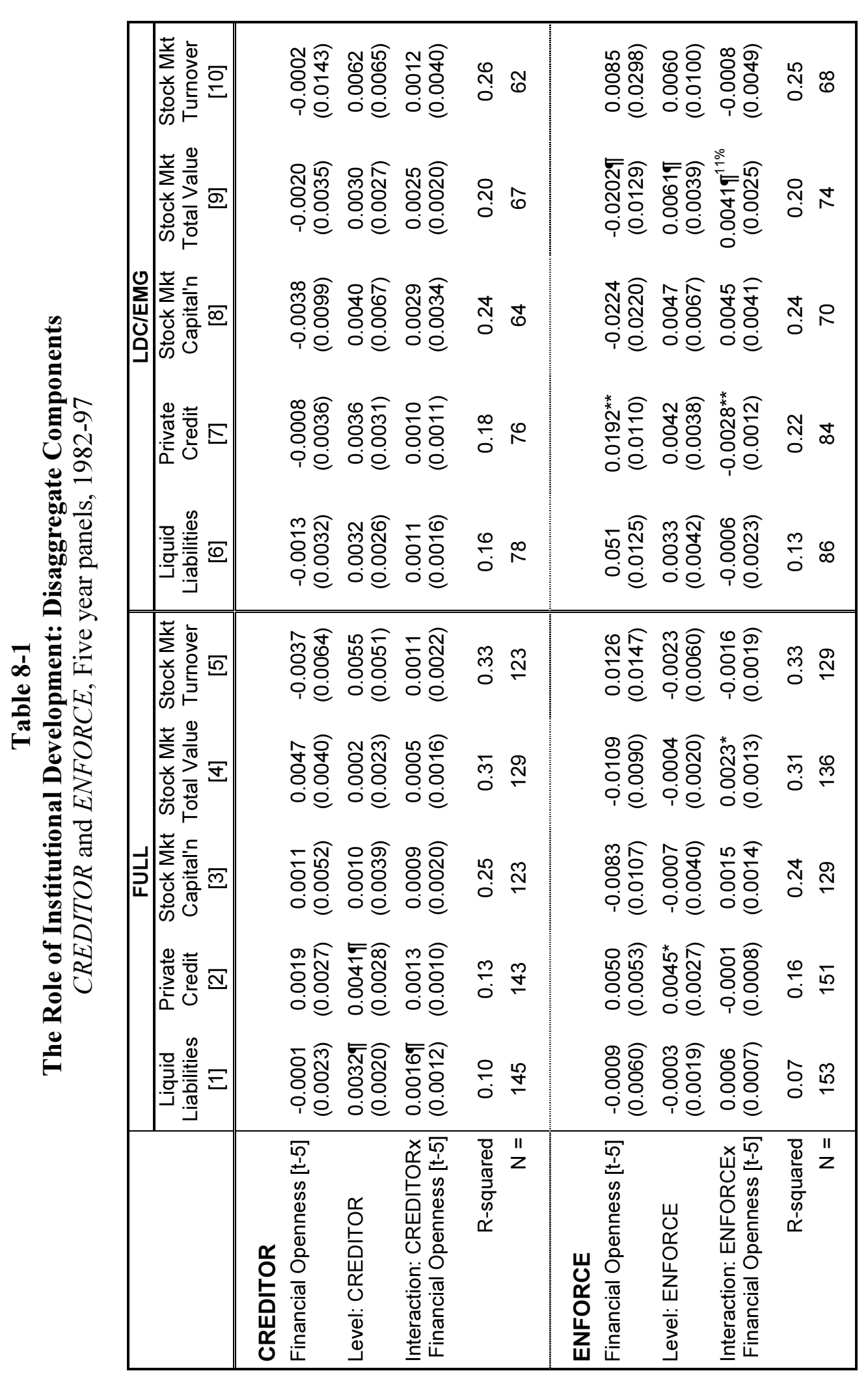

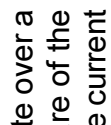

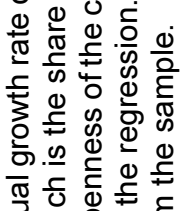

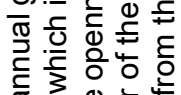

के

שٓ

这

ब过娄

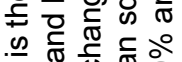

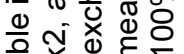

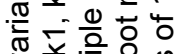

$>\div$ 은 잉

둥

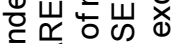

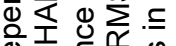

की

क) 은

की

단 응웡

这 है

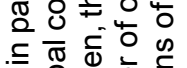

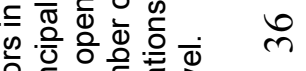

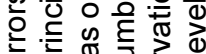

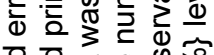

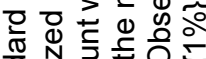

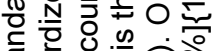

要 交

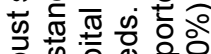

응 के 웡

는 잉영

을

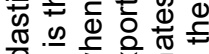

क्षे

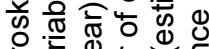

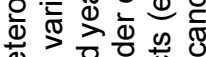

बक क 은

का

○ ญ

$\varepsilon$ 응

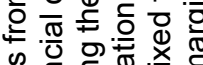

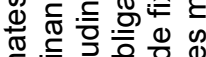

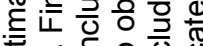

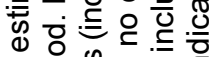

는 웅을

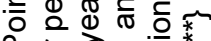

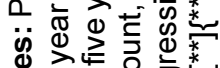

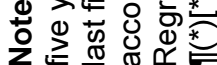




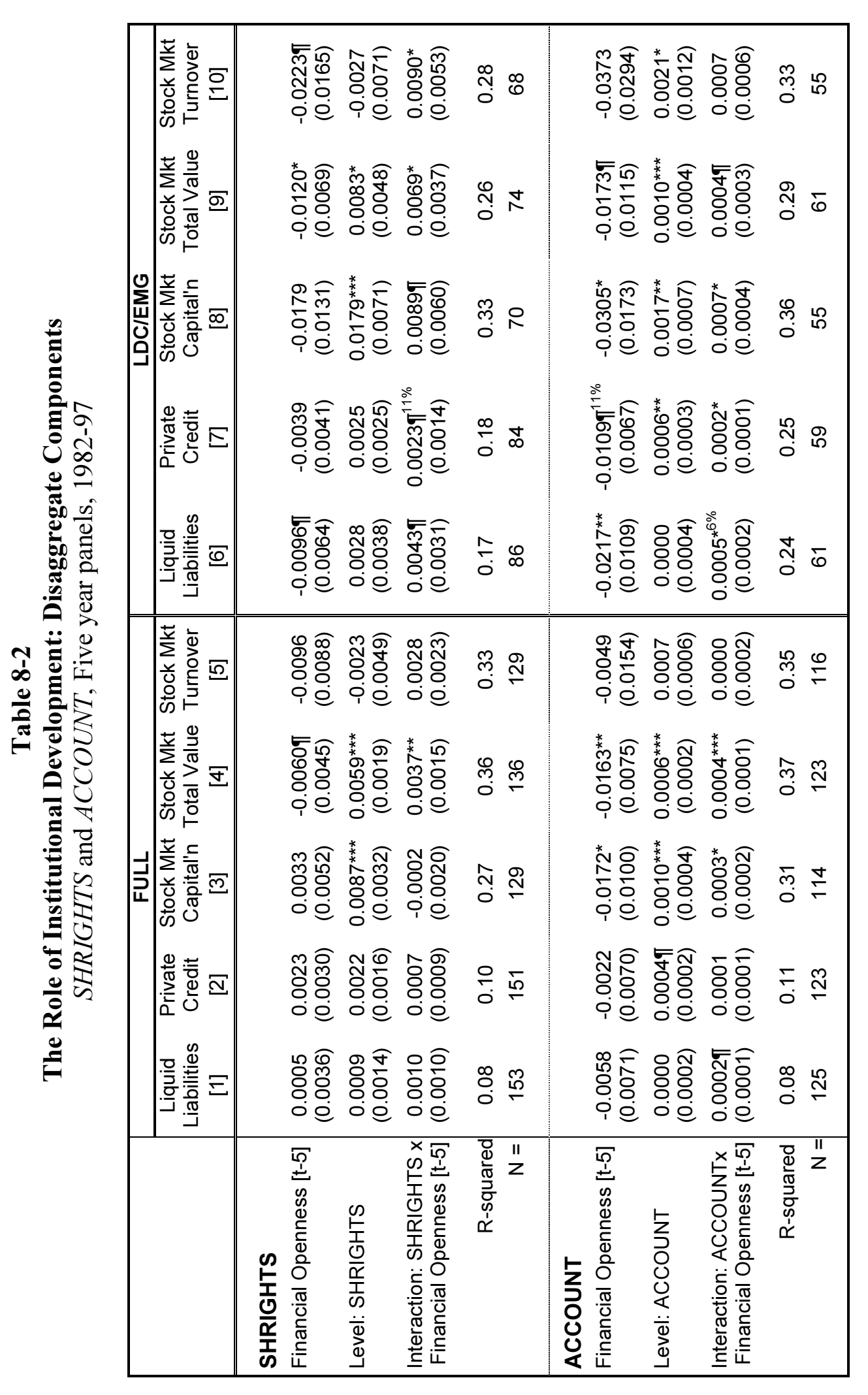

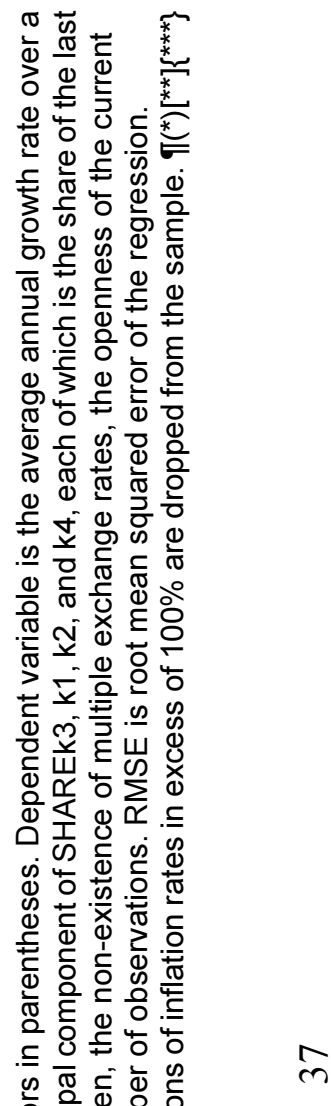

흔 은 응 을 윰

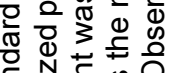

․ㅗㅇ

क

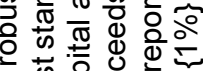

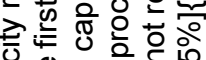

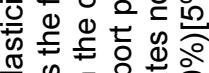

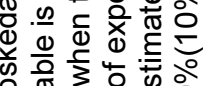

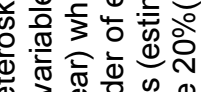

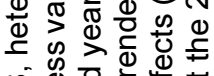

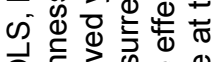

○通离

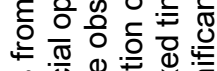

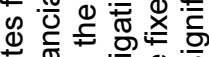

它

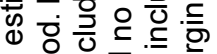

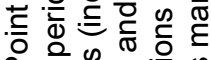

0 市

is

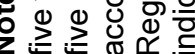


Figure 1

\section{Selected Measures of Financial Deepening}

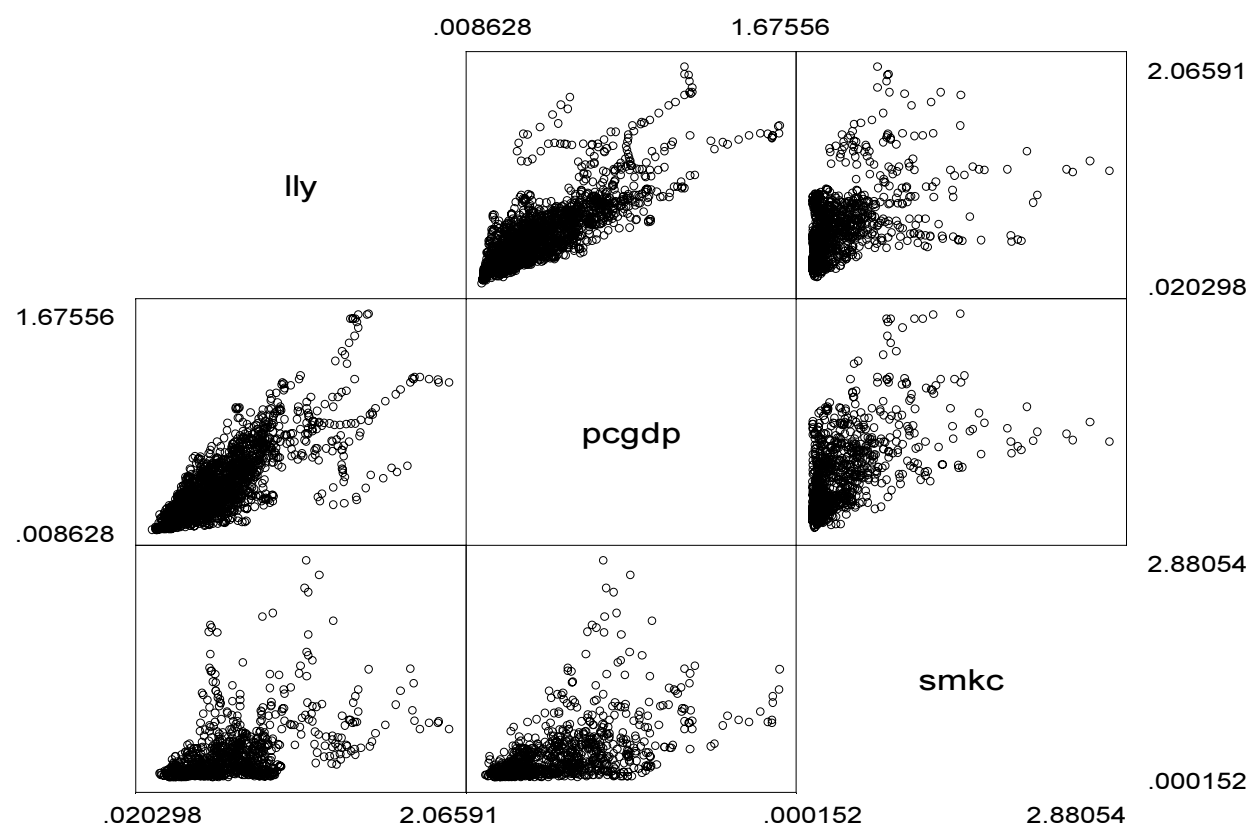


Figure 2

Selected Measures of Financial Deepening and of Financial Openness (KAOPEN)

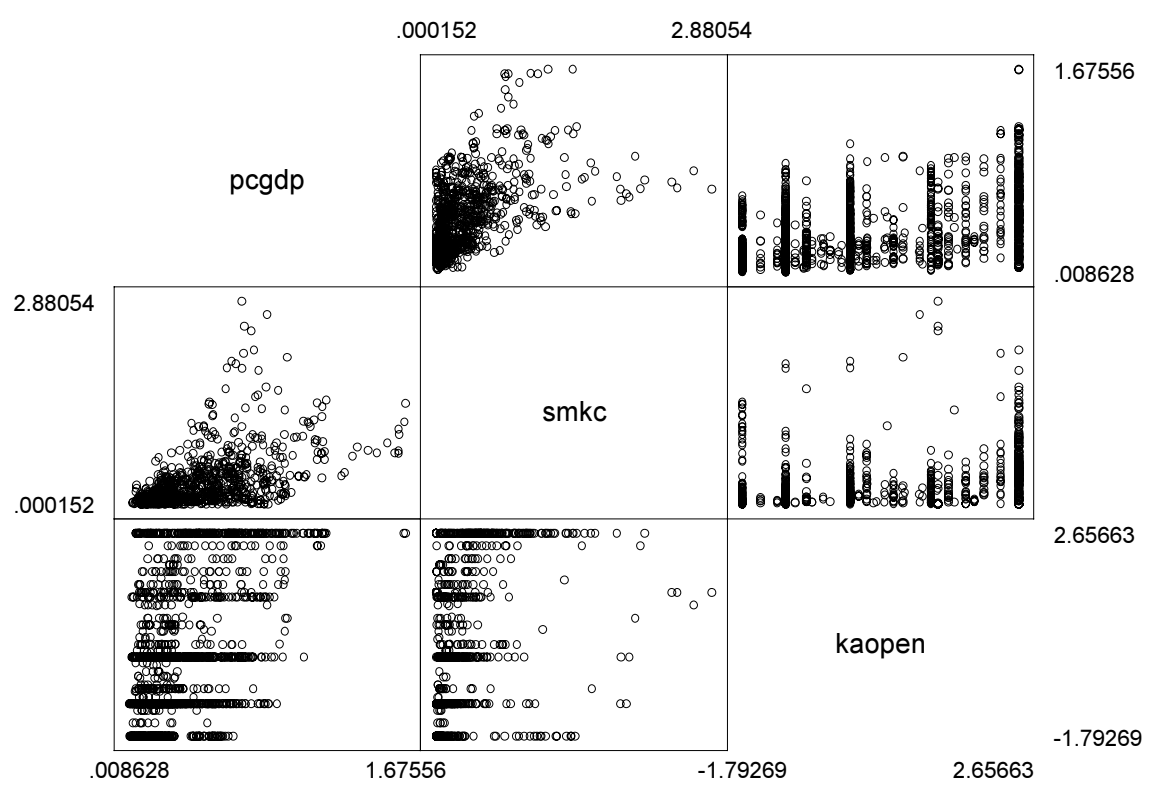


Table A-1

Financial Development and Financial Openness

Using the "Pseudo-Quinn" Measure

Full Sample, Five year panels, 1982-97

\begin{tabular}{|c|c|c|c|c|c|c|c|}
\hline & $\begin{array}{c}\text { Pred } \\
\text { sign }\end{array}$ & \begin{tabular}{|c} 
Liquid \\
Liabilities \\
{$[1]$}
\end{tabular} & $\begin{array}{c}\text { Private } \\
\text { Credit } \\
{[2]}\end{array}$ & $\begin{array}{c}\text { Stock Mkt } \\
\text { Capital'n } \\
{[3]}\end{array}$ & $\begin{array}{c}\text { Stock Mkt } \\
\text { Total Value } \\
{[4]}\end{array}$ & $\begin{array}{c}\text { Stock Mkt } \\
\text { Turnover } \\
{[5]}\end{array}$ & $\begin{array}{c}\text { Equity } \\
\text { Issued } \\
{[6]}\end{array}$ \\
\hline $\begin{array}{l}\text { Financial } \\
\text { Openness [t-5] }\end{array}$ & $(+)$ & $\begin{array}{c}0.0032 \\
(0.0043)\end{array}$ & $\begin{array}{l}0.0083^{*} \\
(0.0043)\end{array}$ & $\begin{array}{l}0.0053 \\
(0.0102)\end{array}$ & $\begin{array}{l}0.0140^{\star *} \\
(0.0065)\end{array}$ & $\begin{array}{l}0.0058 \\
(0.0153)\end{array}$ & $\begin{array}{l}-0.0002 \\
(0.0014)\end{array}$ \\
\hline $\begin{array}{l}\text { Financial } \\
\text { Deepening [t-5] }\end{array}$ & $(-)$ & $\begin{array}{l}-0.0003 \\
(0.0103)\end{array}$ & $\begin{array}{l}-0.0031 \\
(0.0113)\end{array}$ & $\begin{array}{l}-0.0122 \\
(0.0321)\end{array}$ & $\begin{array}{c}-0.0866 \\
(0.0562) \pi\end{array}$ & $\begin{array}{c}-0.1167^{\star \star \star} \\
(0.0306)\end{array}$ & $\begin{array}{c}-0.0560^{\star \star} \\
(0.0243)\end{array}$ \\
\hline $\begin{array}{l}\text { Per Capita } \\
\text { Income [t-5] }\end{array}$ & $(+)$ & $\begin{array}{l}-0.0016 \\
(0.0032)\end{array}$ & $\begin{array}{c}0.0003 \\
(0.0029)\end{array}$ & $\begin{array}{c}0.0047 \\
(0.0068)\end{array}$ & $\begin{array}{c}0.0045 \\
(0.0044)\end{array}$ & $\begin{array}{l}0.0144^{*} \\
(0.0087)\end{array}$ & $\begin{array}{l}-0.0003 \\
(0.0008)\end{array}$ \\
\hline Inflation [t-5] & $(-)$ & $\begin{array}{l}-0.0108 \\
(0.0093)\end{array}$ & $\begin{array}{c}0.0012 \\
(0.0150)\end{array}$ & $\begin{array}{c}-0.0611^{\star * *} \\
(0.0213)\end{array}$ & $\begin{array}{c}-0.0341^{* *} \\
(0.0148)\end{array}$ & $\begin{array}{c}0.0112 \\
(0.0612)\end{array}$ & $\begin{array}{l}-0.0029^{*} \\
(0.0016)\end{array}$ \\
\hline $\begin{array}{l}\text { Trade } \\
\text { Openness [t-5] }\end{array}$ & $(+)$ & $\begin{array}{c}0.0051 \\
(0.0050)\end{array}$ & $\begin{array}{l}0.0075^{\star \star} \\
(0.0037)\end{array}$ & $\begin{array}{l}-0.0217 \\
(0.0182)\end{array}$ & $\begin{array}{c}0.0044 \\
(0.0075)\end{array}$ & $\begin{array}{l}-0.0118 \pi \\
(0.0085)\end{array}$ & $\begin{array}{l}-0.0002 \\
(0.0006)\end{array}$ \\
\hline $\begin{array}{l}\text { R-squared } \\
\mathrm{N}\end{array}$ & & $\begin{array}{l}0.03 \\
198\end{array}$ & $\begin{array}{l}0.08 \\
194\end{array}$ & $\begin{array}{l}0.23 \\
136\end{array}$ & $\begin{array}{l}0.27 \\
142\end{array}$ & $\begin{array}{l}0.36 \\
134\end{array}$ & $\begin{array}{c}0.13 \\
53\end{array}$ \\
\hline RMSE & & 0.023 & 0.025 & 0.045 & 0.037 & 0.067 & 0.003 \\
\hline
\end{tabular}

Notes: Point estimates from OLS, heteroskedasticity robust standard errors in parentheses. Dependent variable is the average annual growth rate over a five year period. Financial openness variable is Quinn's measure of financial openness, linearly extrapolated using the IMF's individual capital control measures. $\mathrm{N}$ is the number of observations. RMSE is root mean squared error of the regression. Regressions include fixed time effects (estimates not reported). Observations of inflation rates in excess of $100 \%$ are dropped from the sample. $\mathbb{I}\left({ }^{*}\right)\left[^{* *}\right]\left[^{* \star *}\right\}$ indicates marginal significance at the $20 \%(10 \%)[5 \%]\{1 \%\}$ level. 


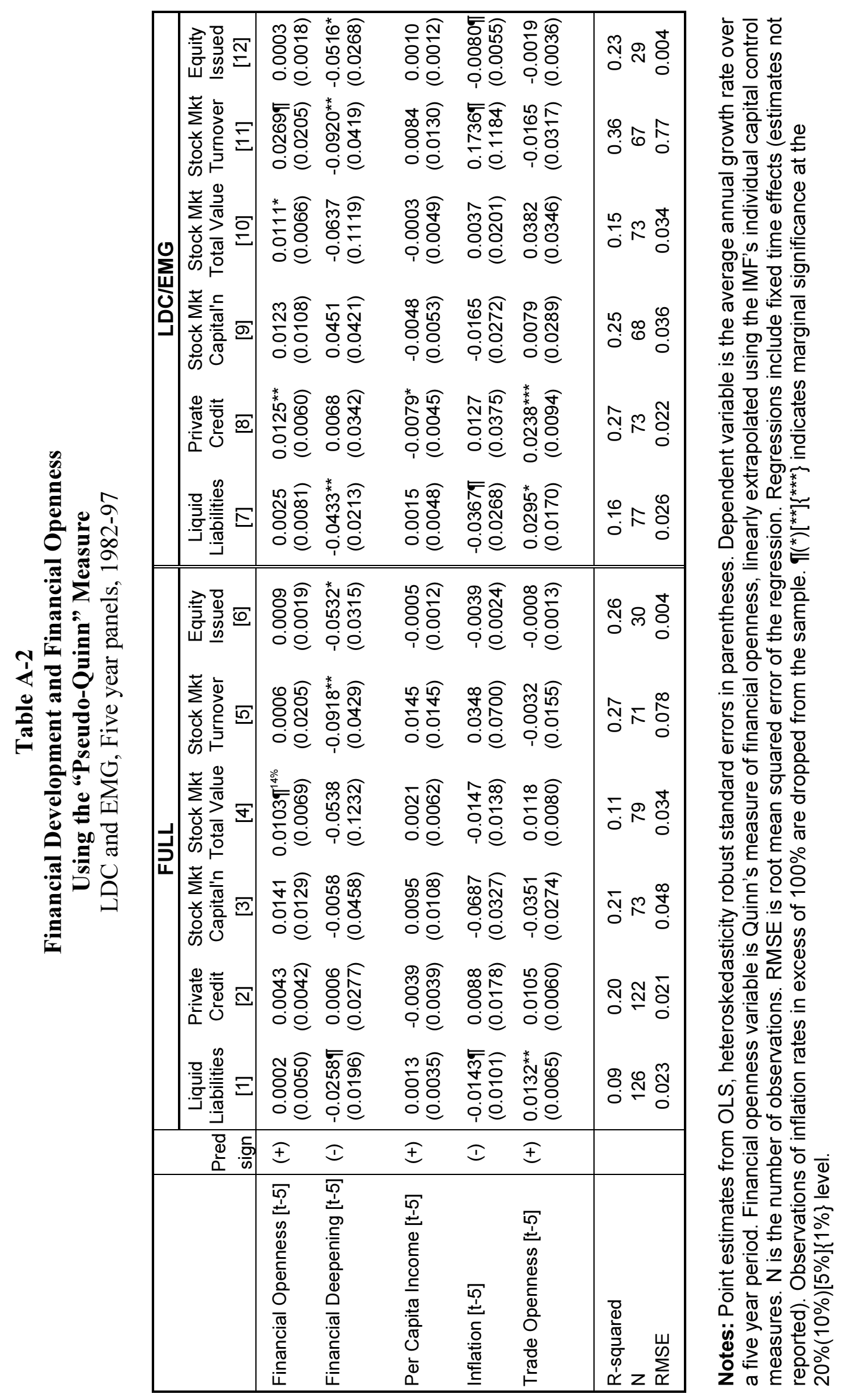


Figure A-1

Financial Openness Measure (Quinn)

For USA and Argentina

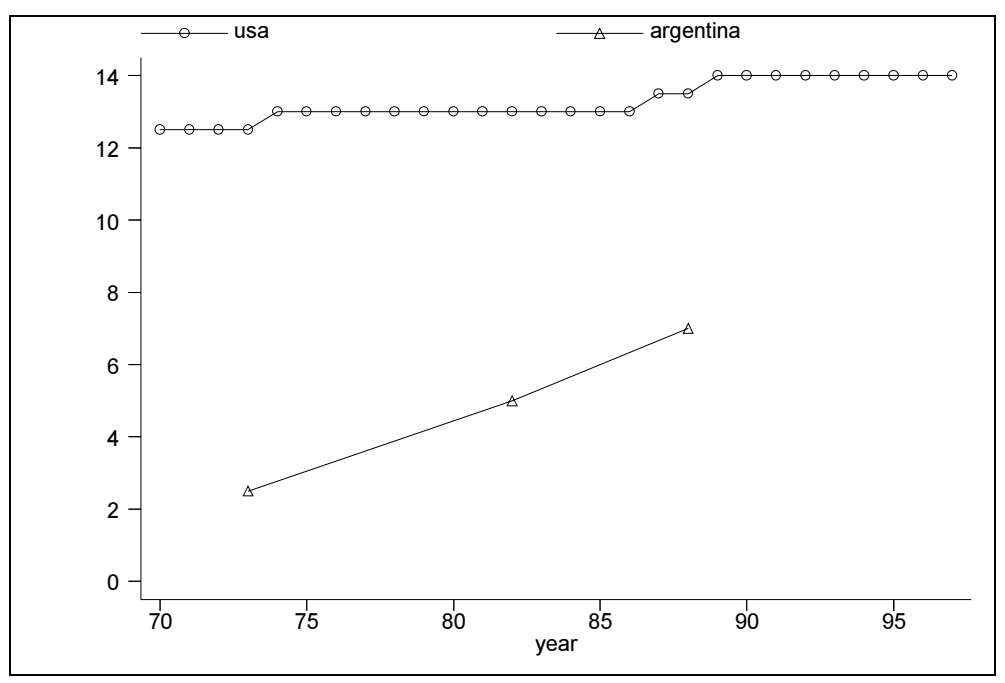

Figure A-2

Financial Openness Measure

KAOPEN vs. "Pseudo-Quinn"

For Argentina

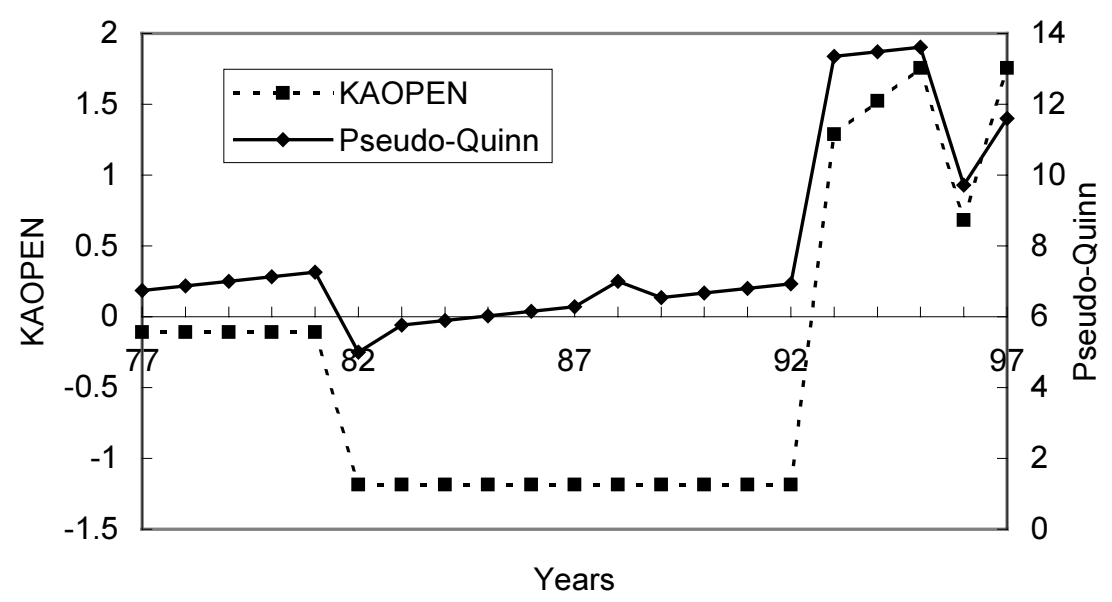

